\title{
La Edad de Oro o la última aventura de Braque
}

\author{
M. ${ }^{a}$ Teresa Jiménez *
}

Las joyas de Braque son ficciones pictóricas, imágenes poéticas que actúan por secretas correspondencias

\begin{abstract}
RESUMEN ABSTRACT
Este artículo comienza con un breve planteamiento de las ideas estéticas de Georges Braque, aquéllas que le llevaron a crear sus joyas. Estas obras son el último eslabón de la evolución del artista. En ellas, como en el resto de sus obras, no imitó a ningún otro creador. Por otra parte, el catálogo de obras que se incluye intenta ser exhaustivo y su exposición, clara y completa.

This article starts with a short exposition of Georges Braque's aesthetic ideas, those which led him to create his jewels. These works are the last link in the evolution of the artist. As in the rest of his works, he never imitated any other artist. On the other hand, the works catalogue, which is included, tries to be exhaustive and its exposition, clear and complete.
\end{abstract}

La joya es concentración de espacio, de forma y de color. Es densidad y fuerza. Exige un arte difícil en su elaboración y composición. La creación es doble en ella. Requiere la sensibilidad del hombre y la seguridad infalible de su mano; aúna, a la vez, imaginación y habilidad del maestro-artesano que interpreta el dibujo del artista y produce milagros: la técnica de fabricación se une a la inspiración del arte.

Georges Braque descubre el universo misterioso de las joyas en donde todo es orden y belleza, formas y colores asociados. Él, que toda su vida

\footnotetext{
* Departamento de Historia del Arte. UNED.
} 
había cantado a través de la pintura, fue seducido por las más raras virtudes de las piedras y de los metales.

No hay exageración en el título del artículo de Claude Salvy, "Cent bijoux de Braque font courir tout Paris", del Journal suisse des horlogers '. Sin duda, a veces, las exposiciones de joyas de artistas - como en el caso de Braque en 1963, en Paris- son más espectaculares que las de pinturas o lienzos. Se conoce al artista, su estilo, sus temas preferidos y se es arrastrado por la curiosidad de ver cómo él ha adaptado sus creaciones a las joyas, a una nueva técnica de expresión.

Es bien conocida la historia de las joyas de Braque. La idea -dice él- le vino al azar. "Pensando que su Cabeza griega podía ser el tema de un camafeo, Braque, un día, colocó una pequeña fotografía sobre un cartón, que colocó alrededor de su dedo. Satisfecho de esta primera tentativa, decidió hacer un anillo para su esposa. Pero le fue preciso, para la realización de su proyecto, un colaborador que conociera muy bien el material y la técnica. Se dirigió al lapidario Heger de Löwenfeld quien se dedicó a traducir lo más fielmente posible los dibujos del pintor. Esto no se hizo sin dificultades, porque el artista no admitía las limitaciones de la herramienta, ya fuese el soplete o la ruedecilla o ruleta. Los oros no eran nunca bastante mates, las formas no se conformaban con las de su imaginación. Algunas joyas, a duras penas terminadas, fueron recusadas de inmediato " ${ }^{2}$. A pesar de todo, dos años después de las primeras experiencias, pudieron exponerse Cien joyas.

Braque, en las joyas repite sus temas preferidos: perfiles, pájaros o peces. Cada pieza lleva un título - generalmente el nombre de un dios o de un héroe de la mitología antigua - con lo que le da un sentido simbólico ${ }^{3}$ :

- Héméra, que lleva a los hombres la luz del día: es un pájaro, todo él de brillantes, sobre una nube de oro con un ópalo rojo claro.

- una Hera en oro se baña en las olas figuradas por un fondo de zafiro.

Es decir, que estas joyas son ya algo más que meros adornos y, en su espíritu, permanecen próximas a la pintura. Las dos artes -pintura y ornamento- se emparentan igualmente por la utilización de los materiales y la composición. Se encuentran generalmente dos planos superpuestos y contrastantes: uno sirve de fondo y el otro está formado por el tema o motivo.

\footnotetext{
Éd. France Art Center, Paris, 1989, págs, 13-90 Ibidem, pág. 14

- Bijoux de Braque, Musées de Nice, janvier-février 1969, y Braque aux Ponchettes, por Hervé
} de FONTMICHEL. 
Las piedras y el oro son, pues, tratados como colores y valores; permanecen como complementos del dibujo y no lo determinan.

Las joyas de Braque, que son demasiado bellas, son pensadas en términos pictóricos - las formas, los planos, los tonos- más que en términos de pura joyería, lo que no le quita nada ni a su encanto ni a su originalidad, pero ha llevado a ciertos críticos a admirar más el talento del maestro que el objeto en sí. Se puede pensar que un joyero habría dicho: la piedra preciosa es Braque.

Raphaël de Cuttoli, en Métamorphoses de Braque ${ }^{4}$, hace una trayectoria por la obra de este artista, analizando su evolución desde su juventud hasta su vejez.

Al parecer, en un primer momento, el joven Georges se inclinó hacia el "fauvismo" (invierno de 1905-1906), pues, como él mismo explica:

Matisse y Dérain me abrieron el camino.

Como no me gustaba el romanticismo, su pintura física me agradaba ${ }^{5}$;

para fundar luego, junto a Picasso, el movimiento cubista ${ }^{6}$. Años más tarde, Braque declara:

No podria representar una mujer en toda su belleza natural. Carezco de la destreza necesaria. Por lo tanto, tengo que crear una nueva clase de belleza, la belleza que se me representa en términos de volumen, de línea, de masa, de peso y, a través de esta belleza, interpreto mi impresión subjetiva.

Opiniones de Braque relevantes e interesantes para comprender el por qué de su deseo de crear joyas en los últimos años de su vida. Podemos observar, desde el primer instante, una inclinación de este artista hacia lo físico, hacia la materia. Él mismo lo admite, cuando afirma, por ejemplo, que,

en la naturaleza muerta hay un espacio palpable, táctil, casi diria manual. Esto respondia al deseo que siempre he tenido de tocar la cosa y no de verla: de ahi mi búsqueda cubista.

Este argumento, unido al afán de Braque por agotar sus obsesiones, según sus propias palabras, y a su preocupación de conjuntarse con la

Paris, juillet 1963, pág. 4

Ibidem. LANLLIEA, Jean y PINI, Marie-Anne, Cinq siècles de joaillerie en Occident. Fribourg, 1971, 300. Raulet, Sylvie, Bijoux des années 40-50. Paris, 1987. Bijoux d'artistes, págs. 221-2 y 226-8.

Lanllier, op. Cit, pág. 303. John CaAven, Les bijoux de Braque. Catálogo exposición del Palacio de los Papas, de Avignon, 1969, y de "Bijoux de Braque», París, 1969. 
naturaleza más que copiarla ', podría aclarar su creación última, sus joyas o esculturas preciosas ${ }^{8}$, como las calificaría el Barón Henri-Michel Heger de Löwenfeld, joyero y ejecutor de los diseños del pintor.

En otra ocasión, Braque habla de su trabajo artesanal en estos términos:

Siempre me he ocupado y preocupado mucho de la materia porque la técnica requiere tanta sensibilidad como el resto de la obra ${ }^{9}$.

Lo cual no le impedirá progresar y, en un determinado punto de su carrera, llegar a conclusiones como ésta:

He hecho un gran descubrimiento -ya no creo en nada. Para mi, los objetos no existen, tan sólo existe una relación armoniosa entre ellos, y también entre ellos y yo. Cuando se alcanza esta armonia se llega a una especie de nada intelectual. De este modo, todo es posible, todo es apto, y la vida es una eterna revelación. En eso consiste la verdadera poesia ${ }^{10}$.

De cualquier modo, Georges Braque le confesará a John Craven que hubiera querido ser escultor y pelearse todos los días con la materia ". Y precisará su regla bajo la fórmula: Impregnación. Obsesión. Alucinación.

El barón Heger de Löwenfeld narra cómo el pintor, que había oído hablar de su talento como joyero - le apodaban el loco o el gentilhombre de la piedra preciosa ${ }^{12}-$, le encargó, como comentamos, que realizara un anillo de aniversario, que queria regalar a su compañera y que habia diseñado el propio Braque. Se trataba de una cabeza griega.

En su primer encuentro, el pintor, que acostumbraba a ser breve y reservado en sus relaciones sociales, conversó con Löwenfeld durante cuatro horas. No hablaron de pintura, sino de piedras preciosas, pero sin referirse a su valor intrínseco, sino a su esencia. Braque desveló al barón que cuando visitaba el Louvre, le gustaba admirar las antigüedades grecoegipcias, pues veneraba el objeto -el objeto es al espacio lo que la música al silencio ${ }^{13}$, habia dicho el pintor-.

CutToli, op. Cit., pág. 27.

Ibidem págs. 27 y 108.

Cuttoli, Braque en ses Métamorphoses, Op. Cit., p.35

- Ibidem, pág. 37 y ZuRCher, Bernerd, Les desseins des ateliers, en Braque. Vie et oeuvre. Fribourg, 1988, pág. 245.

" Curtoli, Op. Cit., pág. 48.

1. Fatidique rencontre avec Georges Braque par Heger de Loewenteld, en Metamorphoses de Braque, op. cit., pág. 106. pág. 96

Odyssée des sculptures précieuses et des bijoux de Braque, en Métamorphoses ... op cit, 
Con una emoción contenida, relata el barón, me presentó su cabeza griega diciendo que le tenia embrujado, que habia intentado veinte veces [...], en vano, liberarse de ella, explicándome que, para él, el cuadro sólo estaba terminado cuando habia borrado la idea y que, al no poder conseguirlo en dos dimensiones, me pedía que la tratara en una tercera dimensión para que la felicidad táctil completara la felicidad visual.. No basta, añadió, con hacer visible lo que se pinta, también hay que hacerlo palpable.[...] Le regalé el anillo al Maestro por su octogésimo cumpleaños, el cual, conmovido y encantado por esta metamorfosis, me pidió con fervor que le liberara de otros temas que le tenian embrujado y que liberara, sobre todo, al pájaro, simbolo del Espacio y del Tiempo, de la esclavitud de la jaula del cuadro ${ }^{14}$.

En efecto, como afirma Raphaël de Cuttoli, el pájaro, que emprende el vuelo y se sale del decorado como para escapar a su entorno, constituirá un tema central ${ }^{15}$ en la obra del artista a lo largo de toda su vida.

El maestro, que había dicho, para mí, no más metáforas, sino metamorfosis ${ }^{16}$, quedará tan satisfecho con la creación de Heger de Löwenfeld, que le pedirá realice otras joyas. De este modo, ambos artistas trabajarán en estrecha colaboración durante los tres últimos años de vida del pintor -desde octubre de 1961 hasta la víspera de su muerte a finales de agosto de 1963-.

Braque, impregnado de cultura antigua, y de común acuerdo con Heger de Löwenfeld, decidió que toda la obra estaría consagrada a los dioses y diosas de la mitología helénica, eso sí, interpretados bajo su visión metafísica tan personal, de ahí que la mayoría de sus joyas se parezcan ${ }^{17}$. En ese sentido, puede apreciarse la influencia que tuvieron sobre él autores griegos - como Heráclito de Efeso-, que le deslumbrarían con sus particulares filosofías; o poetas, como Saint-John Perse.

Raphaël de Cuttoli cuenta cómo, en septiembre de 1962, fueron a parar a manos de André Malraux, Ministro de Estado encargado de los Asuntos Culturales de Francia, algunas joyas que le había presentado Heger de Löwenfeld, y cómo Malraux, deslumbrado por tan hermosas creaciones, exclamó: ¡Es extraordinario!, es la apoteosis de Braque. Quiero cien de estas joyas para exponerlas en la galería de Apollon ${ }^{18}$.

El 21 de marzo de 1963, se inauguró la exposición titulada Cien joyas de Braque eri el Museo del Louvre, en el Pabellón de Marsan, siguiendo

Fatidique... op cit, pág. 106.

CutTOLI, op. cit, pág. 40.

Odyssée des sculptures..., op cit, pág. 98 y ZUACHER, op cit, pág. 250.

ANDERSON BLACK, J., A History of Jewellery, London, 1981, pág. 292.

Braque en ses métamorphoses...op cit, pág. 45. 
las indicaciones del barón, quien ordenó cómo debían disponerse las joyas. El éxito de la exposición fue tal que se prolongaría hasta el 13 de mayo y el Estado estimó su deber adquirir once de estas joyas que, actualmente, se encuentran a buen recaudo en el Banco de Francia. En seguida, otras ciudades y países se interesaron en esta exposición. De modo que Estados Unidos, a la cabeza, obtuvo el consentimiento del artista y los ministros, para trasladarla por barco, el 31 de agosto de 1963, día en que, curiosamente, fallecería Braque.

El barón Heger de Löwenfeld cuenta la premonición que tuvo el artista y pintor cuando se despidió de él el 25 de agosto. Evocando el Viaje de Baudelaire, Braque le habló así:

Si uno puede quedarse, se queda, pero si debe partir, parte... yo puedo hacerlo, porque tú me has liberado... Gracias ${ }^{19}$

El embajador de Francia en Estados Unidos, Hervé Alphand, encargado de organizar dicha exposición en Nueva York, escribe en la presentación del catálogo a la misma:

Georges Braque, maestro soberano de los colores, conoció al final de su vida esta suprema tentación - la de la materia más dura y casi inmutablela piedra preciosa en su esplendor misterioso y fascinante ${ }^{20}$.

Braque - al igual que Dali-, opinaba que ni el metal, ni la piedra tienen valor en si mismos, y que el hombre había sometido las gemas a una servidumbre, al clasificarlas en piedras preciosas, semipreciosas, etc. Este artista les devolverá su valor estético, según su teoría de que el pintor piensa en formas y en colores y de que el objeto es la poesía ${ }^{21}$.

De ahi que se pueda aseverar sin temor, que las joyas de Braque son ficciones pintorescas o imágenes poéticas, y que el artista, al consagrar la plenitud de sus dones a este arte, liberó las piedras preciosas del lastre que arrastraban desde hacía varios milenios, concediéndoles una forma de expresión nueva. Pues, como él mismo pensaba: Jamás descansaremos. El presente es perpetuo ${ }^{22}$.

\footnotetext{
Fatidique rencontre... Op cit., pág. 108. ZuRCHER, op cit, pág. 250.

20 Métamorphoses de Braque... op cit, pág. 94. También Hervé Alphand en Hommage à Braque. De la presentación del Catálogo de la exposición americana, s.p.

${ }_{21}$ Michel FARE, Bijoux de Braque, Gimpel et Hanover Galerie, Zurich, junio-julio 1963, pág. 1, y LANLLIER, op cit, pág. 303.

22 Michel FARE, lbidem, pág. 2.
} 
Léon de Groër, en su introducción al catálogo de la exposición del museo de Niza ${ }^{23}$, apunta con acierto que Georges Braque no cedió jamás a la facilidad, ni sacrificó su arte a las modas, quizá por eso logró dar vida a las piedras preciosas y revivir el arte de la orfebrería de un modo tan original.

Braque, como Dalí, en sus joyas, repitió los temas que venía recreando en lienzos y esculturas o relieves. En su taller real eran usuales tales decoraciones: esculturas en forma de peces de diversas y parecidas formas; cabezas de caballo, etc. $Y$ en sus lienzos, observan expectantes perfiles femeninos, a veces dobles, y, sobre todo vuelan pájaros, aquéllos que dieron fama universal a seis de sus ocho Talleres, pájaros nacidos de la mano del pintor, no legendarios, míticos, sino un simple signo de vida, como el que representará a Pandora ${ }^{24}$.

Como siempre, en Braque, las formas son nacidas de la observación más atenta de los acontecimientos de la vida cotidiana y no del deseo de colocar algún símbolo en su pintura. Durante el verano de ese año de 1955, vuelve a Camargue, donde visita una reserva de pájaros, admirando el vuelo mjestuoso de las flamantes rosas en su largo cuello. Así se lo cuenta a Verdet: Por encima de los estanques, he visto pasar grandes pájaros. De esta vision he deducido unas formas aéreas. Los pájaros me han inspirado, ensayo extraer el mejor perfil para mi dibujo y mi pintura. Me es necesario, sin embargo, borrar de mi memoria su función natural de pájaro. Como siempre, en Braque, las formas son nacidas de la observación más atenta de los acontecimientos de la vida cotidiana y no del deseo de colocar algún símbolo en su pintura. Durante el verano de ese año de 1955, vuelve a Camargue, donde visita una reserva de pájaros, admirando el vuelo mjestuoso de las flamantes rosas en su largo cuello. Así se lo cuenta a Verdet: Por encima de los estanques, he visto pasar grandes pájaros. De esta visión he deducido unas formas aéreas. Los pájaros me han inspirado, ensayo extraer el mejor perfil para mi dibujo y mi pintura. Me es necesario, sin embargo, borrar de mi memoria su función natural de pájaro.

Unos temas espirituales han tomado forma. Braque, en sus joyas, ha despejado el valor hermético del pájaro ${ }^{25}$. El ser espacial, precisamente hijo de Hermes, había ya cautivado a Leonardo da Vinci. Bajo el mismo signo, en el cielo de su pensamiento, uno y otro han expresado el deseo

\footnotetext{
Léon de Groër, Bijoux de Braque, Museos de Niza, enero-febrero 1969, pág. 4

ZURCHER, op cit, pág. 257-26.

ZurChEr, op cit, Le vol de l'oiseau, págs. 250 y 254. Guillaume, S., Introducción al Catálogo de la Exposicicón de "Cent bijoux", op. cit. , Nancy.
} 
de pintar el infinito: el pájaro de Braque había chocado contra el techo de un palacio, según la tradición de Leonardo da Vinci traducida por Valéry:

El gran pájaro emprenderá su primer vuelo montado sobre un gran cisne / llenando el universo de estupor, / invadiendo con su gloria todas las escrituras; / alabanza eterna al nido en el que él nació.

He aquí que el pájaro se convirtió en una joya. Su vuelo triunfa entre las nubes. Aliado a la trama tenue de la noche, palpita como la estrella de Artemisa. En la cima de una nube, se otea otra joya: un astro nos ofrece un doble rostro inquietante, a la vez de frente y de perfil (llithye, Persephone). Vuelto hacia el cielo, la cabeza mariposa se metamorfosea; llevada hacia el río y el Léthé de los mares, la cabeza de pescado evoca el recuerdo de su origen más lejano. Joya ésta, ahora libertada de los mares, de la que presentamos su sentido esotérico: el rostro reposa sobre una ola de esmeraldas (Hebe). Al contacto con el agua helada, se conforma y se convierte en ánfora. Con el paso del tiempo, el signo de la transmigración evoluciona. El sol de las aguas ha disipado las sombras. El fénix ${ }^{26}$ va a renacer del fuego. Liberado de la tierra, sube al aire y lo flanquea, en un último vuelo de noche.

Que el Fénix nace y renace / Que su corazón que late lata por el mundo entero! / Tanto cuanto vivamos, cantará / Viene la muerte, él nos sobrevivirá

No se podia olvidar esta suerte de iniciación que espontáneamente se estableció sin ayuda extraña. Braque se inspiró en los libros antiguos. No hay mayor transmisión que la que uno mismo hace, en una lectura reflexiva y descifrante. Cuando Ambrosio Vollard le confió la ilustración de la Teogonía de Hesiodo ${ }^{27}$, el artista reflexionó sobre el espejo de Los Trabajos y los Días. Así lo haría en otras ocasiones. Los cantos de Milarepa, maga, poetisa, eremita tibetana del siglo XI, se impusieron a la meditación de Braque. Determinadas ilustraciones fueron también graba-

\footnotetext{
Edith Rose, Oda a los pájaros de Braque.

Poeta del siglo vill a.C. La Teogonia trata de la creación del mundo: la Noche engendra la tierra y los monstruos, pero también el cielo y la luz. De la unión múltiple de la tierra y el cielo nacieron los dioses de la mitología griega, los más y los menos conocidos. Braque amaba este texto, se sentía atraido por la creación del mundo, por el paso del caos al orden, tan parecido al trabajo del artista. En el centro de los grabados, Braque representa a un personaje de la Teogonía, por ejemplo, sobre la primera el Poeta y su musa, después diferentes divinidades, de las que, a veces, inscribe el nombre en caracteres griegos. En los bordes esboza algunas imágenes reconocibles o disimuladas, que representan el caos, mientras que la o las figuras centrales muestran el orden que ha tomado forma. Dora VALLIER, L'oeuvre gravé de Braque. Tout l'oeuvre gravé de Georges Braque. Tokyo, 1984, s.p.
} 
das en cierto sentido en algunos de sus lienzos. Sin embargo, el más grande de los iniciados, Heráclito de Éfeso, lo iba a cautivar.

Georges Braque ha grabado, pues, un frontispicio con Zetes y Calais, para la traducción de Heráclito de Éfeso por Yves Battistini, en la que René Char había añadido un prefacio. El pintor, más tarde debía conocer a otros poetas, como Saint John-Perse ${ }^{28}$, y todos unidos harán reinar el Orden de los Pájaros. Las joyas reflejan el juego de estos encuentros.

Braque, promete a la piedra un rostro con el brillo de un ojo, el temblor de la nariz, la respiración entre los labios simulados. La noción clásica del objeto se ha sobrepasado: el objeto está unido a un sujeto. Como el universo es único y viviente, esta relación no es sólo accidental sino permanente y fecunda.

Igualmente le atrae la imagen del caballo, que simboliza, principalmente, el transcurso del tiempo y se le suele asociar al movimiento de los astros, al sol y a la luna. Las diosas lunares y los dioses solares de los griegos, escandinavos o persas, viajan sobre vehículos tirados por caballos. Desde su nacimiento estaba revestido de carácter sagrado. Más tarde se le asocia a la virilidad, a la potencia. En realidad es un simbolo ambiguo, de las tinieblas y la muerte. Por ello, Platón lo veía unido a las tinieblas y a la luz. El cráneo del caballo es símbolo de la potencia sagrada y de la unión profunda con el misterio. La imagen del caballo engendra la del jinete, la acción y la violencia ${ }^{29}$.

Todo el conjunto tiene, para muchos, un valor de símbolo. $Y$ en la exposición de FRED ${ }^{30}$ (París, VI Biennale des Antiquaires de 1972) se presentan las joyas originales que provenian del Louvre $y$, siguiendo la

\footnotetext{
En su actividad como grabador Braque ha destacado como ilustrador de textos, mas sólo de los que él amaba. La mayor parte pertenecen a sus amigos poetas - Apollinaire y Reverdy, en primer lugar; después, Saint-John Perse, Saint-Paul Roux, Francis Plonge y, entre los más intimos, René Char.

La Société des Éditions d'Art, Au Vent d'Arlés, publicó en Paris la edición original de Oiseaux, en 1962, presentada con el título L'Ordre des Oiseaux, par Saint-John Perse et Georges Braque, en gran edición artistica con las aguafuertes originales del pintor. La Biblioteca Nacional de París hizo una exposición de la gran edición artística de L'Ordre des Oiseaux, con unos manuscritos de Saint-John Perse y los cobres grabados de Braque. Edición expuesta más tarde en Washington, en la Biblioteca Nacional del Congreso. En 1963, Gallimard hizo una publicación de Oiseaux, traducido en Estados Unidos por Walace Fowlie y, posteriormente, en España por Manuel Alvarez Ortega (Madrid, Visor, 1976).

Martine Torrens, La imagen poética de Saint-John Perse. Temas y simbolos. Salamanca, Universidad de Salamanca, 1983, págs. 117-120.

3i. Desde la exposición del Louvre en 1963, las joyas de Braque se expusieron en numerosos museos o galerias de todos los paises del mundo entero, pero, ningún joyero, salvo FRED, ha presentado esta colección. Ésta parece ser la razón que ha movido a dicha firma a realizarla.
} 
voluntad de Braque, las derivadas de las piezas expuestas allí, idénticas a su original, ya que son esculpidas por la misma mano, pero, sin embargo, diferentes por la elección de las piedras preciosas que las componen. Heger de Lowenfeld, como Braque, es el creador, y cada derivado original sigue siendo una pieza única ya que nunca ha sido reproducida en la misma combinación de color.

Integran la Colección ciento cuarenta piezas, llamadas arquetipos, porque datan de la vida de Braque, según sus dibujos y sus maquetas, y llevan su firma. Varias fueron adquiridas por los museos y grandes coleccionistas, trece por el Estado francés, y siete piezas robadas en 1970 en el Museo de Nîmes y encontradas en junio de 1972 estimadas en 150 millones de franco antiguos.

Braque deseaba que Löwenfeld continuase su obra. Por ello, antes de morir, encomienda a su esposa deje a favor de Löwenfeld los derechos concernientes a sus esculturas preciosas y a sus joyas. Ésta, el 24 de noviembre de 1964, firmó un documento en el que precisaba que Heger de Löwenfeld tenía todos los derechos de reproducción de obras sin ningún pago cualquiera que fuese su situación y la de sus descendientes. Por su parte, Löwenfeld declaraba que, como había estipulado en un contrato anterior, de 6 de junio de 1962, entre Braque y él, se limitaría a la reproducción de cada arquetipo en un solo ejemplar en cada combinación posible de metales y materiales. Él pidió que de cuarenta de ellas se hiciesen réplicas. De cada réplica podían editarse setenta y cinco ejemplares que, si bien no llevan la firma del artista, si lleva la mención de Joya de Braque ${ }^{31}$. En lo concerniente al trabajo del oro puro, reproduciría unas series de setenta y cinco piezas en todas las combinaciones de materiales.

Es un conjunto maravilloso. Al lado del proyecto de Circe, se pueden ver las numerosas piezas que han permitido realizar esta toma del espacio que Braque ambicionaba. Expresan las leyendas de la Fábula de los personajes de los dioses, de las diosas, de las ninfas, los héroes y de los animales mitológicos. Las piedras y los metales preciosos evocan alternativamente a Zeus y Deméter, Selene, Afrodita, Medea, Anfión, Perséfone, Atenea, Eros y Psique, Anfítrite, Pandora, Electra, las Tres Gracias, Fénix, la corcel Atalanta, la ninfa Aretusa transformada en fuente, las pléyades metamorfoseadas en pájaros, Hías en estrella y otros cien personajes fabulosos.

Perfiles (hasta 33), peces (26), cabezas de caballo (3), dragones (2), astros (2), mariposas (3) y sobre todo pájaros (59), adornan los anillos y

\footnotetext{
31 AlPHAND, Bijoux d'artistes contemporains. Paris, 1974, pág. 4
} 
las cadenas. Pájaros grabados en cornalina india, en diamantes, en oro, en calcedonia, en rubíes, en lapislázuli, esculpidos en negro sobre blanco, sobre un ónice bicolor. Las realizaciones más diversas revelan originales combinaciones: camafeos a la antigua, pájaros grabados sobre crisoprasto o en oro macizo sobre un motivo de turquesa rodeado de diamantes, pájaros, esculpidos en tres tonos o colores, figuran en diamantes sobre fondo de peridotos, etc.

Una de las piezas maestras de la colección es el Neo-Glaucos, que mide $140 \mathrm{~cm}$. y pesa $50 \mathrm{Kg}$. El cuerpo del pez es de amatista, la cola de oro macizo. Su ojo es un diamante de 74 carates, valorado en 240 millones de francos antiguos. La madrina de esta joya es Juliette Achard.

La primera exposición de las joyas de Braque, como dijimos, tuvo lugar en marzo de 1963, en el Museo del Louvre, Pavillon de Marsan, recibida como el acontecimiento artístico del año. A partir de ella se suscitó un extraordinario interés que ha cristalizado en treinta y una ${ }^{32}$ exposiciones internacionales, que se han sucedido hasta nuestros días en diferentes capitales y, principalmente, en Estados-Unidos, Europa y Japón. En varias de estas exposiciones, como en la de Nancy, se presentan litografías, gouaches y pinturas en relación con las joyas ${ }^{33}$, y aún, a veces, completada por la muestra de camafeos no montados, obras en curso de realización y minerales (col. Löwenfeld) excepcionales ${ }^{34}$.

\footnotetext{
32 Paris. Palais du Louvre - Pavillon de Marsan- 22/3 -13/5/63 - 36.000 visitantes.- Zurich. Gimpel \& Hanover Galerie- 18/6-15/8/63. 18.000 vts.- S/S “France". Exposition flottante avec vernissage à bord au Havre et à New York- 30/8-4/9/63. 5.000 vts.- Dallas. Neiman-Marcus. 9/921/9/63. 17.000 vts. Houston Neiman- Marcus- 23/9-5/10/63. 13.000 vts.- San Francisco. De Young Memorial Museum. 18/10-18/11/63. 65.000 vts.- Pittsburgh. Museum of Art Carnegie Institute2/12-29/12/63. 16.000 vts.- Kuala-Lumpur. National Art Gallery- 1/5-31/7/64. 27.000 vts.- Munich. Die Neue Sammlung - 15/6-20/7/64, 20.000 vts.- Darmstadt. Hessisches Landesmuseum 10/12/64-14/2/65. 32.000 vts.- Cannes. Casino Municipal - 20/12/64-5/1/65. 25.000 vts.- Bruxelles. Palais des Beaux-Arts - 13/1-7/2/65. 28.000 vts.- La Haye. Gemeentemuseum- 12/2-4/4/65. 24.000 vts.- Rotterdam. Museum Boymans-Van Beuningen - 15/3-25/4/65. 27.000 vts.- Kansas City. William Rockhill Nelson Gallery of Art - 28/4-5/6/65. 23.000 vts.- New-York. Wally "F» Galleries 8/10-12/11/65. 22.000 vts.- Montréal. Musée des Beaux-Arts de Montréal - 25/2-18/3/66. 31.000 vts.- New-York. Finch College Museum of Art - 15/3-30/4/66. 28.000 vts.- Quebec. Musée de Québec - 23/3-5/5/66. 72.000 vts.- New-York. Cartier - 12/5- 28/5/66. 12.000 vts.- Carennac. Prieuré de Carennac - 3/7-30/9/66. 6.000 vts.- Tokyo. Isetan - 14/9-28/9/66.

40.000 vts.- Paris. Galerie Staedler - 2/4-11/5/68. 8.000 vts.- Cologne. Galerie Der Spiegel - 1/1231/12/68. 5.000 vts.- Nantes. Galerie Argos -1/12-31/12/68. 6.000 vts.- Nice. Musée des Ponchettes - january-february 69. 6.000 vts.- Hanover. Galerie Brusberg \& Foire Internationale -march-april 69. 100.000 vts.- Avignon. Palais des Papes - 15/6-15/9/69. 175.000 vts.- Cannes. Palm-Beach - 1/9-15/9/69. 15.000 vts.- Bonn. Galerie Wunsche - 17/2-28/2/70. 5.000 vts.- Nimes. Musée des Beaux-Arts - 5/5-7/6/70. 6.000 vts.- Antibes - Juan-les-pins. Casino Municipal - 10-13/6/70. 5.00 vts.- Lyon. Gelerie Verrière 20/10-12/11/70. 20.000 vts.- Biievres (Essonne). Moulin de Vauboyen - 2/12/70-15/1/71. 20.000 vts.

3. S. Guillaume, Les 100 bijoux de Braque ... Musée des Beaux-Arts de Nancy, 1973, pág. 6.

34 Catálogo exposción Museo Louvre, 1963.
} 
Fue un trabajo enorme y el tiempo apremiaba. André Malraux, fascinado por las primeras realizaciones y ante la edad avanzada del artista, expone:

es necesario que Braque, que deja alrededor de 2.000 pinturas dispersas por el mundo, nos legue también este patrimonio artístico sin precedentes en la obra de un pintor ${ }^{35}$.

El por qué estas preciosas esculturas se han reservado al final de su vida, nos lo revela Löwenfeld. Estaba obsesionado por algunos temas de la creación: la cabeza griega, el pájaro... Las pinturas de ellos no lo habían liberado. Él contemplaba el lienzo y se interrogaba sobre una tercera dimensión que se oculta detrás del cuadro ${ }^{36}$. Los collages en la época cubista y más tarde la arena mezclada con la pasta, para darle más relieve, no le satisfacian.

Cuando agrandaron en tapiceria la cabeza griega, no le dejó tranquilo. Sin embargo, intentó lo contrario, la miniaturización de dicho tema, en los dedos de Löwenfeld. Es así como nació el Camafeo de Circe, reproducción reducida de la cabeza de inspiración cretense. Una impresión inexplicable de belleza, de magia, emana de este perfil esculpido, de este sueño sellado en la piedra.

Preciosas arquitecturas del infinito, las joyas de Braque, que, para André Malraux, son su apoteosis, quedarán como la última etapa de un largo paseo en una vida enteramente dedicada a lo nuevo, a la creación, a la meditación, a la metamorfosis. Constelaciones últimas, compuestas y esculpidas antes del gran viaje presentido, parecen ser la más joven, la más radiante de sus obras.

Y ello es porque la búsqueda de Braque es absoluta e intemporal; no quiere ni asombrar, ni provocar entusiasmos ruidosos. Su obra es secreta, exigente y $\sin$ compromiso. Es una armonía severamente conquistada entre la razón y el corazón, entre la técnica y la inspiración. En Braque toda forma está controlada; todo color es medido, atenuado en su brillo y llamado a un destino espiritual ${ }^{37}$.

Braque ha probado, siguiendo a los grandes artistas del Renacimiento, que la orfebrería es también, como la pintura y la escultura, capaz de pro-

Braque en ses métamorphoses... op cit., pág. 45.

Zurcher, op cit. L'état des lieux, 237-44 y Le dessein des Ateliers, 244-50

Christian Zervos, Braque inventor en Georges Braque, exposició de septiembre a noviembre de 1979. Madrid, March, s.p. 
ducir unos signos en los que el lujo se trasciende en belleza o en los que la preciosidad de la materia se olvida por no ser sino un acto de armonía fijado para siempre.

\section{JOYAS DE BRAQUE}

La relación de las Joyas de Braque en los diferentes Catálogos responde a una numeración arábiga, en la que recoge, quizás, la cronología de elaboración de las piezas. Dado que todas fueron realizadas en menos de dos años, hemos creído más interesante agruparlas por temas y, en éstos, seguir un orden alfabético. En la ficha técnica de cada joya, se da la bibliografía en que se la cita y el número correspondiente o página de cada Catálogo. La bibliografía completa puede verse al final. A su vez, en letra cursiva, damos el comentario estético e indicamos la obra pictórica o gráfica en que se inspiró directamente el artista. La interrelación mutua entre literatura y arte, entre Braque y Hesíodo o Saint-John Perse, por ejemplo, se explicita en el texto.

ASTRO:
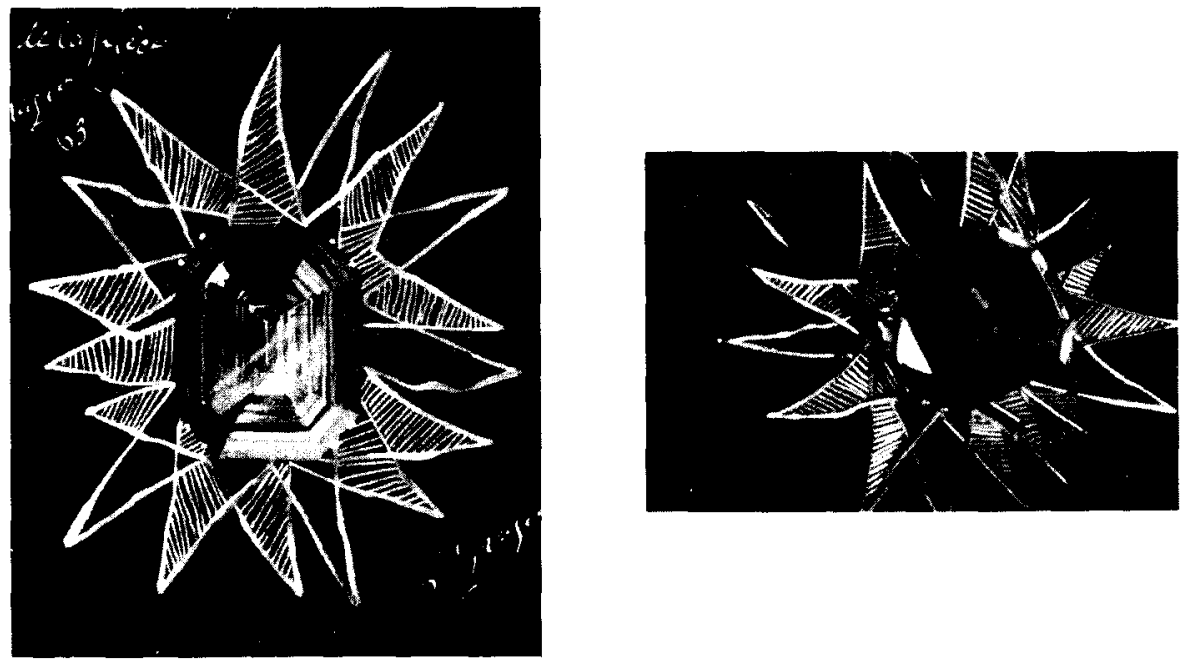

HelIOS. A través de su casco de oro, sus ojos lanzan chispas cegadoras y de su seno parten rayos brillantes. Motivo de $150 \times 175 \mathrm{~mm}$. Cuarzo topacio excepcional de $60 \times 73 \mathrm{~mm}$, con un peso de 810 quilates, adornado 
con rayos de vermellón. Bijoux de Braque, Museos de Niza, enero-febrero 1969 , 83; Zurich, 83; Nancy, 45; CRAVEN, 24.

Rodos. Sus rayos iluminan el cielo. Hilos de oro aureolando una citrina. $70 \times 70 \mathrm{~mm}$. Nancy, 100 .

\section{CABALLO:}

Aeton. Camafeo. Cabeza de caballo perfilada ( $34 \times 52 \mathrm{~mm}$ ), colocada sobre la madera silificada $n .^{\circ} 5049$. John CRAVEN, 36.

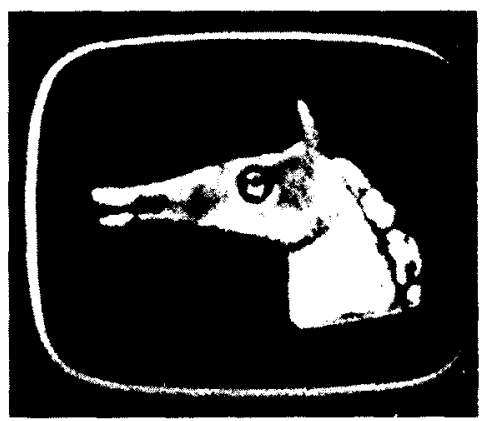

AETON II. El carro del sol atraviesa el cielo tirado por caballos blancos alados brillantes entre los que se encuentra Aetón. Cabeza de caballo perfilada en un jade. 34 × $52 \mathrm{~mm}$. Nancy, 56 .

AETON /l. Camafeo. Cabeza de caballo negro sobre blanco en un ágata bicolor. $23 \times 30 \mathrm{~mm}$. Nancy, 79 .

AEton IV. Cabeza de caballo esculpida en jade. $80 \times 120 \mathrm{~mm}$. Nancy, 77. Recuerda la "Cabeza de caballo", de 1946 (escultura en bronce, del Museo de Arte Moderno de París).

AREION II. Es fruto de los amores de Deméter y Poseidón. El valiente corredor va a salvar a Adraste que va a combatir a Tebas. Broche. $35 \mathrm{x}$ $52 \mathrm{~mm}$. Cabeza de caballo perfilada en oro, con el ojo de ópalo. Bijoux de Braque, Museos de Niza, en-febr 1969, 17; Nancy, 11; Craven, 19.
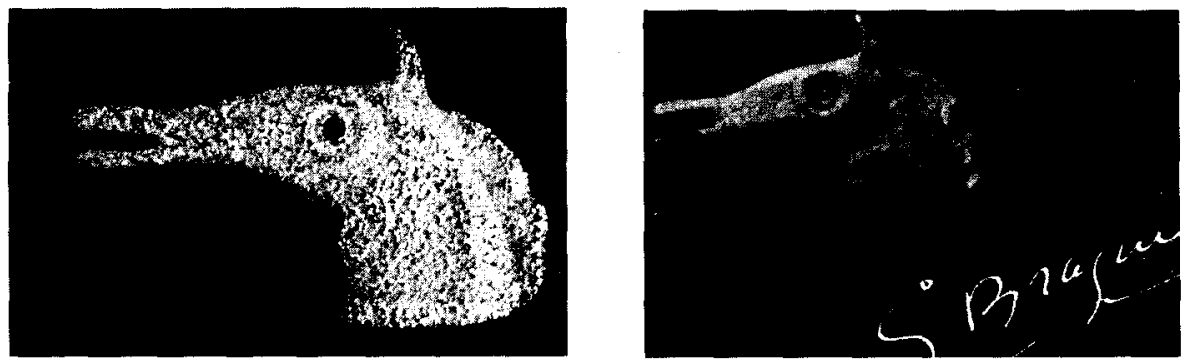
AREION II. Broche $35 \times 52 \mathrm{~mm}$. Cabeza de caballo perfilada en oro con el ojo de rubí. Bijoux de Braque, Museos de Niza, enero-febr. 1969, 17. Zurich, 17 ; Staedler, 17.

Tanto "Aetón" como "Areion»están próximos en su representación al "Pequeño caballo", de 1939, en bronce, $y$ al de 1941-42.

Pyroels. Conducido por Helios, el valiente corredor escala la bóveda del cielo. Clip. $35 \times 41 \mathrm{~mm}$. Cabeza de caballo de oro, afiligranada de platino y punteada con una esmeralda. Bijoux de Braque, Museos de Niza, enero-febrero 1969, 11. Zurich, 11; Nancy, 8; Staedler, 11.
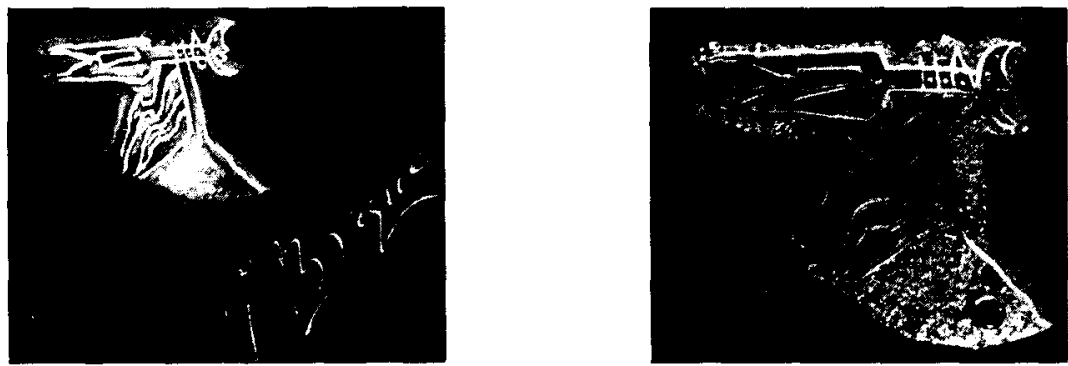

Pyroeis reproduce la iconografia de unos relieves en bronce ("Eolo I" y "Eolo Il», de 1939, y unas litografias, "Helios l», de 1946).

\section{ESTRELLA:}

ARTEMISA. Sobre las montañas borrascosas, sobre las cumbres batidas por los vientos, la diosa tiende su arco resplandeciente. Clip. $44 \times 44 \mathrm{~mm}$. Estrella de oro pulido y de oro mate y diamantes. Bijoux de Braque, Museos de Niza, enero-febrero 1969, 2; Zurich, 2. (Fig. izquierda).
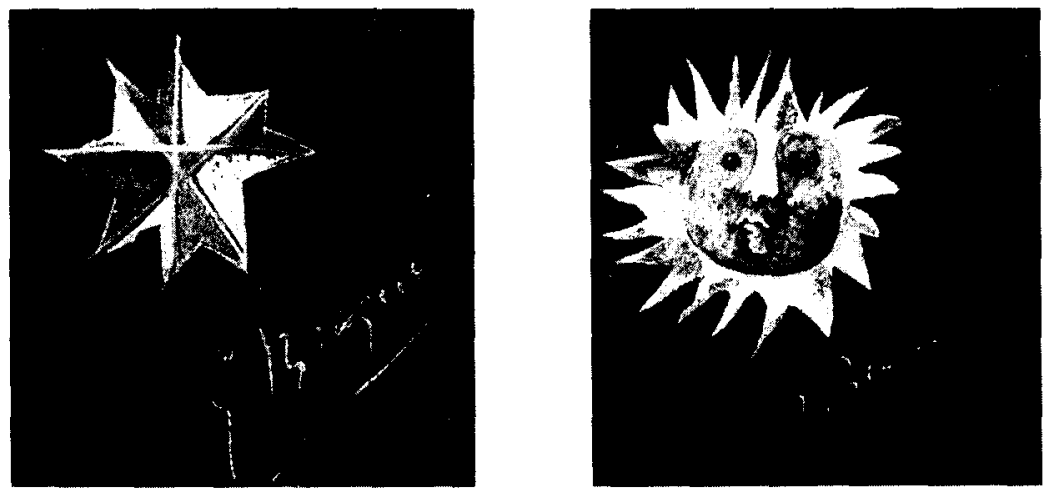
Eudora. Nacida de los ardientes amores de Helios con la voluptuosa Oceánide Tersée. (Fig. derecha en página anterior).

HIAS. Como no desea separarse de su hermano, devorado por un león, ella se metamorfosea en estrella para acompañarle. Clip. $36 \times 45 \mathrm{~mm}$. Estrella de diamante sobre una rodocrocita orbicular excepcional. Bijoux de Braque, Museos de Niza, en-febr. 1969, 26; Zurich, 26; Nancy,19; Craven, 30 .
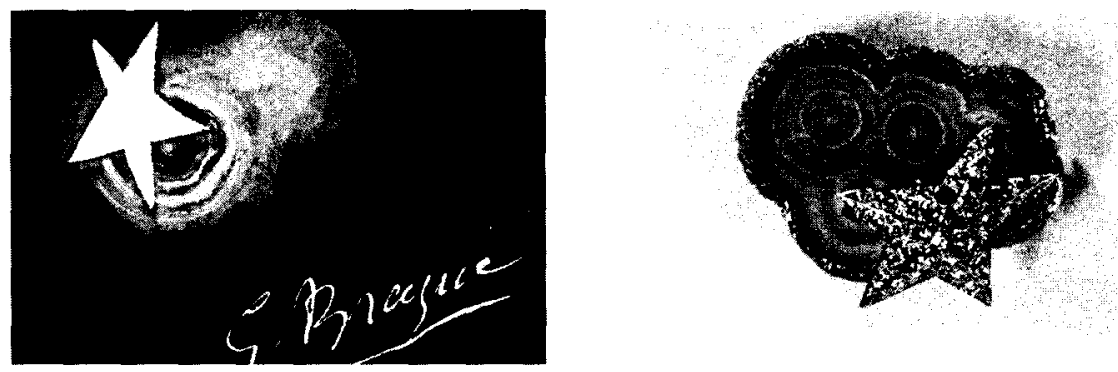

LEUCOTHÉE. Es el nombre que los habitantes de la Isla de Rodas dieron a Halia, arrojada al mar. Estrella de oro, rubí y diamante. Zurich, 48; Craven, 33.

LeUCOTHEE II. Compasiva con los marinos, los guía a través de las tempestades. Clip. $75 \times 85 \mathrm{~mm}$. Estrella de mar de oro pulido y desgastado, punteada de piedras preciosas. Bijoux de Braque, Museos de Niza, en.-febr. 1969, 48; Nancy, 34.

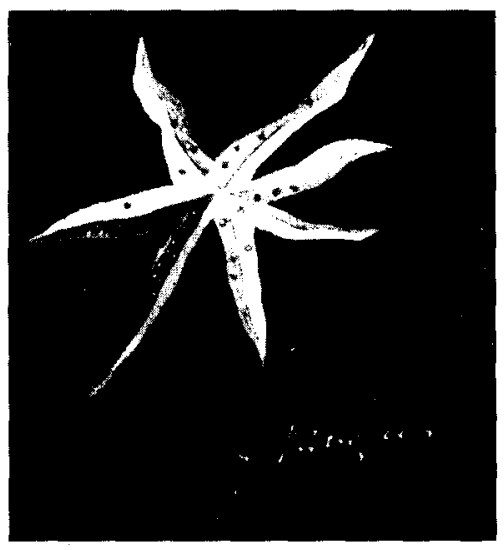

\section{MARIPOSA:}

COERON. El antepasado de las Coerónides instaurará el culto a Deméter. Mariposa esculpida en negro sobre blanco en un ónice bicolor de $15 \times 21 \mathrm{~mm}$. Bijoux de Braque, Museos de Niza, enero-febrero $1969,98$. 
COERON II. Mariposa esculpida en negro sobre blanco en un ónice bicolor de $23 \times 30 \mathrm{~mm}$. Bijoux de Braque, Museos de Niza, enero-febrero 1969, 99; Nancy, 49.

MEGARINA. El descenso de Triptolemo ayuda a Arcas a enseñar a cultivar el trigo. Anillo de platino, adornado con una mariposa de diamantes, de $32 \times 38$ mm. Bijoux de Braque, Museos de Niza, enero-febrero 1969, 77; Craven, 28.
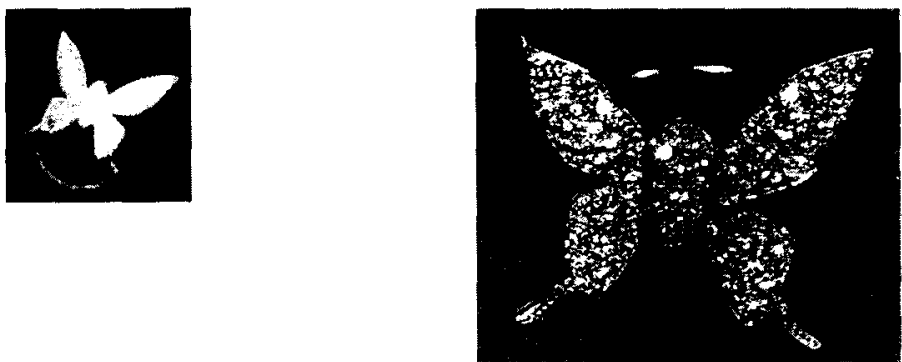

TRIPTOLEMO. Según la orden de Deméter, el héroe eleusino recorre el mundo sembrando granos de trigo y haciendo florecer las cosechas y las flores. Clip. $50 \times 75 \mathrm{~mm}$. Mariposas de diamantes libando en flores de rubíes sobre un fondo de oro. Bijoux de Braque, Museos de Niza, enero-febrero 1969 y Zurich, 1963, 30.- CRAVEN, 26 y CRAVEN, 1969, p. 77; Staedler, 30.

TRIPTOLEMO IV. Deméter confía a Triptolemo el primer grano de trigo. Anillo de platino adornado con una mariposa de diamante, $38 \times 32 \mathrm{~mm}$. Bijoux de Braque..., 1963, n. ${ }^{\circ} 77$; Zurich, 77.

"Megarina" $y$ "Triptolemo" repiten el mismo diseño, sea en gouache $o$ en la joya, sólo una mariposa o varias en conjunto.
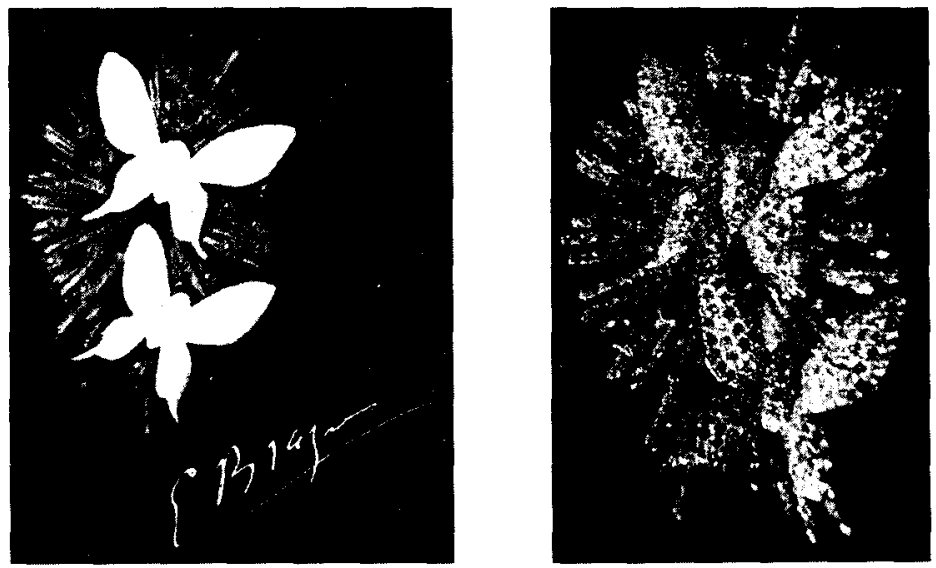


\section{PÁJAROS:}

Desde principio de los años 50 hasta su muerte, Braque realizó numerosos lienzos con temas de pájaros. En ninguna de estas obras intentó copiar el vuelo del pájaro, sino que procuró plasmar el movimiento en el espacio, al margen de toda preocuipación realista.

Los pájaros en vuelo de Braque son siempre formas sencillas y esquemáticas, que parecen flotar, más que volar sobre cielos de un azul compacto y denso. Más que figuras simbólicas, las aves de Braque son experimentos pictóricos.

Las diferentes pinturas y las representaciones del tema en la serie llamada "los Talleres", son siempre similares y diversas a las trasposiciones realizadas en las joyas. Pandora parece tomada del Taller VI; los modelos en vuelo, con alas extendidas, geométricas o curvadas, se repiten en ambas materias, como es frecuente en las obras de todo creador.

“... Éstos son los pájaros de Georges Braque. más cerca del género que de la especie, más cerca del orden que del género, dispuestos para reunir en un mismo rasgo el tronco materno y el avatar, jamás hibridos y sin embargo milenarios...»

Canto XII. Saint-John Perse. Trad. M. Alvarez

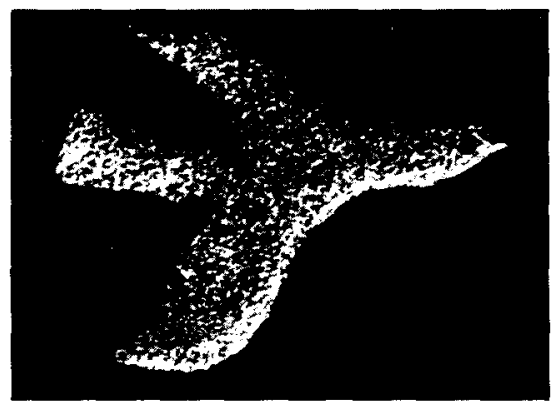

ACrisios. Nació de la extraña unión entre Céfalo y un oso. Pájaro de oro con un ojo de esmeralda. $48 \times 65 \mathrm{~mm}$. Craven, Las joyas de Braque/Les bijoux de Braque, Festival d'Avignon, Palais des Papes, juinseptembre, 1969, p. 84 y n. ${ }^{\circ} 11$.

ACRISIOS. En Argios reinaba Acrisios, padre de Danae. Pájaro de oro con ojo de zafiro. $46 \times 65 \mathrm{~mm}$. Nancy, 68 .

ACRISIOS II. Broche $46 \times 65 \mathrm{~mm}$. Pájaro de oro desgastado con el ojo punteado con un rubí. Bijoux de Braque, Museos de Niza, enero-febrero 1969; Bijoux des artistes contemporains, $\mathrm{n} .^{\circ} 24$. 
AEGLÉ. La ligera Hespéride se dirige a pleno vuelo hacia la manzana de oro. Clip. $36 \times 53 \mathrm{~mm}$. Pájaro de diamantes con el ojo de rubí de Oriente, sobre un fondo de turquesa. Bijoux de Braque, Museos de Niza, en-febr 1969, 15; Nancy, 10; Zurich, 15.
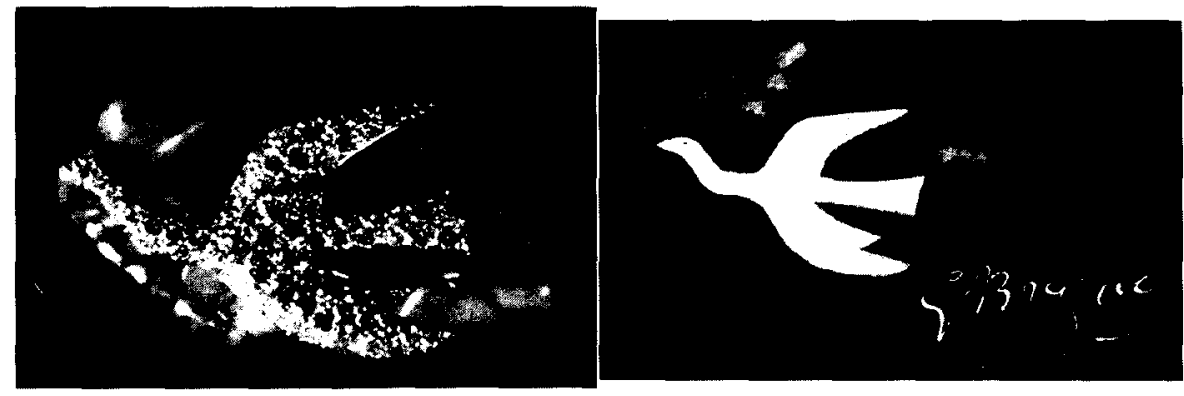

AEGLÉ III. Con sus compañeras vigila los jardines de los Dioses. Caja. $83 \times 54 \mathrm{~mm}$. Ágata paisaje y oro. Bijoux de Braque, Gimpel et Hanover Galerie, Zurich 2, jun-jul 1963, 73.

AETER. En el infinito celeste, engendrará al sol. Pájaro y astro esculpidos en negro sobre blanco, en un ónice bicolor de $15 \times 21 \mathrm{~mm}$. Bijoux de Braque, Museos de Niza, enero-febrero 1969. John CRAVEN, s.n. ${ }^{\circ}$ y p. $18, n .^{\circ} 96$.

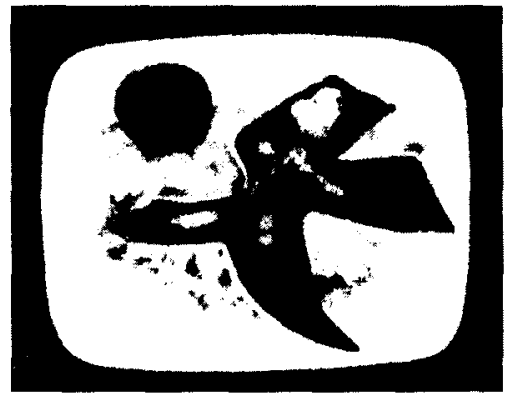

AETER II. Pájaro y astro esculpidos en negro sobre blanco en un ónice bicolor de $23 \times 30 \mathrm{~mm}$. Bijoux de Braque, Museos de Niza, enero-febrero 1969, 97. Braque, Galérie Staedler, Paris, 1968, n. ${ }^{\circ} 97$; Nancy, 48.

AFRoDITA. Conducida por Hermes se reúne con Hera y Atenea para ser juzgada por Paris en el monte Ida. Pájaros esculpidos en tres tintes degradados del blanco al pardo, montados en clip de oro. Bijoux de Braque, Museos de Niza, enero-febrero 1969, 76.

ALCIÓN. Tras calmar a los vientos, Zeus permite al fabuloso pájaro que construya por fin su nido lejos del mar con delicadas ramas. Collar de oro con motivo engastado de diamantes. Adquirido por el Estado francés. Bijoux de Braque, Museos de Niza, enero-febrero 1969, 13. Zurich, 13. 


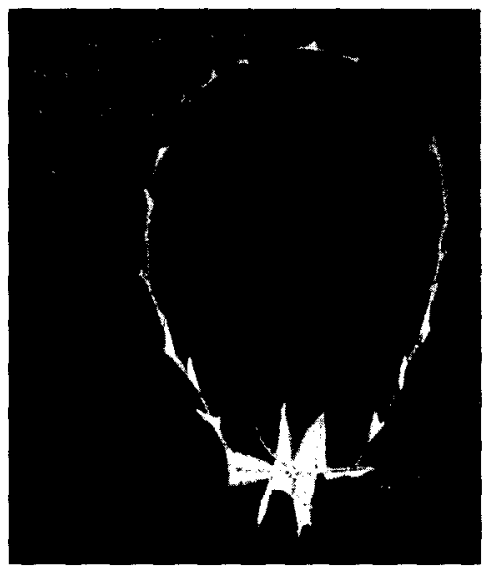

AMFIÓN. Es el hijo de Zeus y de Antíope y hermano gemelo de Cetos. Amfión tocaba la lira, con cuyos dulces sonidos salvó a su madre de la prisión e hizo también elevarse las piedras que formaron las murallas de Tebas, donde reinaron. Amfión murió alcanzado por una flecha de Apolo. Pájaro esculpido blanco sobre negro en un ónice bicolor. Anillo de oro. 15 $\times 21 \mathrm{~mm}$. Nancy, 87; Craven, s.n.

Asteria. Para escapar de las persecuciones de Zeus, la hija de Febo se transforma en pájaro. Clip. $80 \times 80 \mathrm{~mm}$. Pájaro tejido con elementos de oro, ojo de diamante naveta. Adquirido por el Estado francés. Bijoux de Braque, Museos de Niza, enero-febrero 1969, 57 ; Zurich, 57; Craven, 20.

Asteria. Pájaro tejido con adornos de oro gris y ojo de zafiro. Nancy, 41.

ASTERIA II. Clip. $80 \times 80 \mathrm{~mm}$. Pájaro afiligranado de plata adornado con un ojo de turquesa. Bijoux de Braque, Museos de Niza, enero-febr. $1969,57$.
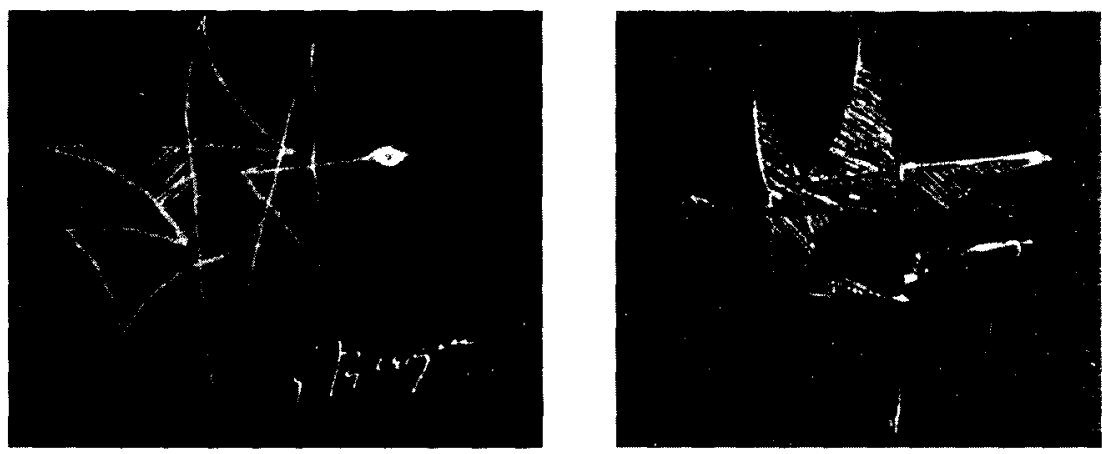
ASTERIA IV. Clip. $80 \times 80 \mathrm{~mm}$. Pájaro afiligranado de oro, adornado con un ojo de turmalina. Bijoux de Braque, Museos de Niza, enero-febrero 1969, 57.

En 1953 realizó un relieve en bronce-piedra, titulado "El pájaro", con este mismo diseño, el cual también repitió tres años después en el "Cartel de Exposición", en óleo sobre papel de periódico. Ambos podian ser el ensayo del tema de esta joya.

AstRAEOS. Unido a Eos, el fabuloso Titán engendra los astros. Dos pájaros de oro pulido y parecido al granito. Nancy, 94 .

ATENA. Para vengarla de Paris, Heracles le ofrece las manzanas de las Hespérides. Pájaro de oro y jade. $56 \times 24 \mathrm{~mm}$. Nancy, 84 .

BóREAS. El genio del viento vuela hacia el llisos. Calcedonia excepcional gris-azul, trabajada en caja de $77 \times 125 \mathrm{~mm}$., en la que está engastado un pájaro de oro desgastado. Adquirido por el Estado francés. Bijoux de Braque, Museos de Niza, enero-febrero 1969, 72.

Inspirado en el óleo "Pájaro atravesando una nube».
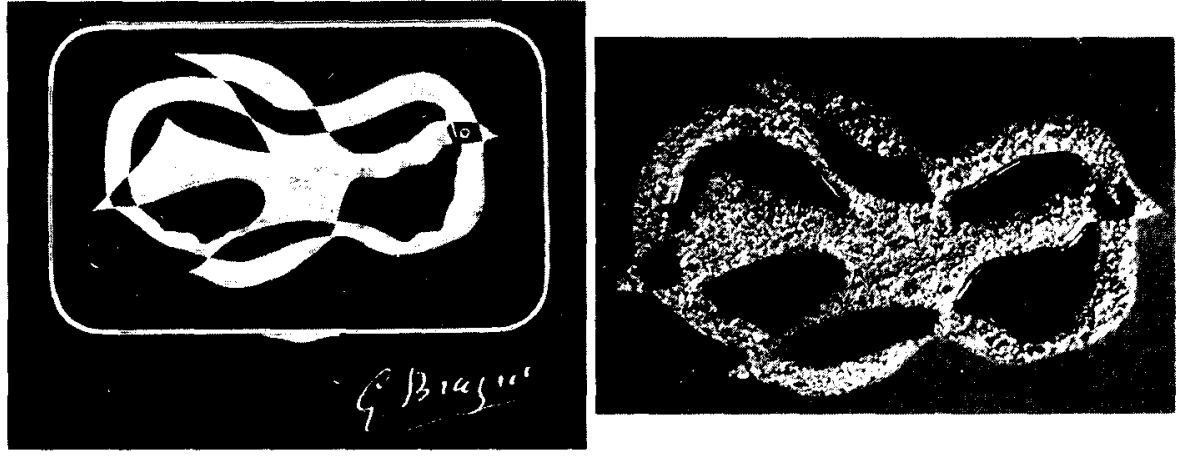

ANTIBÓREAS. El Titán que vuela hacia el lliso planea el rapto de Orithye. Broche. $38 \times 61 \mathrm{~mm}$. Pájaro de oro sobre una nube de lapislázuli rodeado de oro. Bijoux de Braque, Museos de Niza, en.-febr. 1969, 4; Zurich y Staedler, 4.

ANTIBÓREAS II. El gran pájaro despliega sus alas sobre una sombría nube. Pájaro de oro sobre fondo de esmalte azul. Clip. $61 \times 38 \mathrm{~mm}$. Zurich, 72; Nancy, 3.

CALAIS. El hijo de Bóreas reina sobre los vientos favorables. Pájaro de oro y ojo adornado con una esmeralda. 43 × $45 \mathrm{~mm}$. Nancy, 83 .

CaliPSO. Convertida en pájaro, puede resistirse al encanto de Orión. Pendientes de clip. $25 \times 36 \mathrm{~mm}$. Pájaro de diamantes en oro calado. Bijoux de Braque, Museos de Niza, enero-febr. 1969, 43; Nancy, 31. 
CÉFALO. Habiéndose retirado a Tebas, el hijo de Hermes concluye su vuelo en Cefalonia. Clip. $52 \times 72 \mathrm{~mm}$. Pájaro de oro sobre otro pájaro de jade y de diamantes, que figura como su sombra. Bijoux de Braque, Museos de Niza, enero-febrero 1969, 9; Zurich, 9; Staedler, 9.

Semejante diseño aparece en diversas litografías, grabados y pinturas, principalmente en las aguafuertes de "L'ordre des oisseaux", de SaintJohn Perse y de Braque, de 1962.
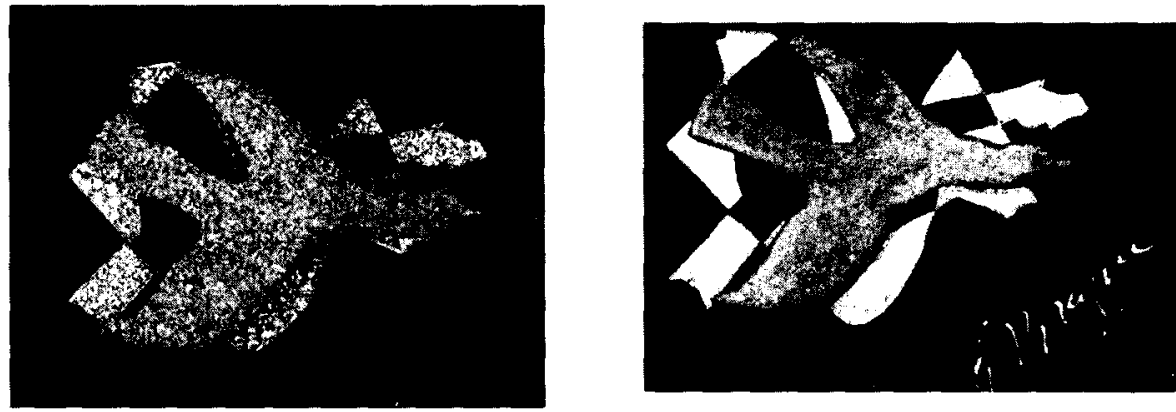

CÉFIRO. El dios ofrece su anillo nupcial a las hijas de Electra. Pájaro de diamantes montado en anillo de platino. $23 \times 30$ $\mathrm{mm}$. Bijoux de Braque, Museos de Niza, enero-febrero 1969, 33; Nancy, 22; Craven, 29.

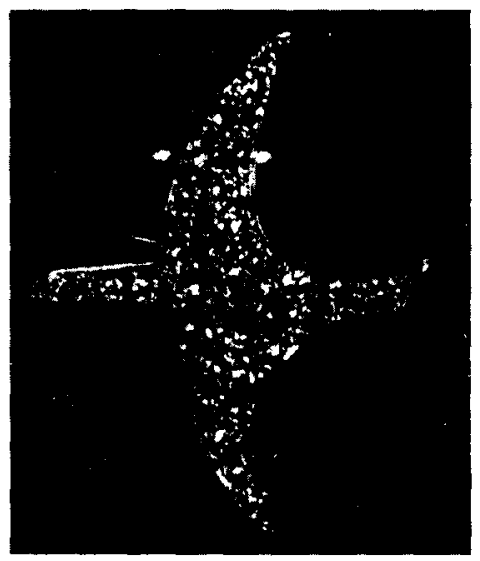

CYknos. Cyknos significa le Ciygne, el cisne. Abandonado, se arroja al lago Canope y Apolo lo transforma en cisne. De una extraordinaria belleza. Pájaro en oro amarillo y oro blanco. $40 \times 80 \mathrm{~mm}$. Bijoux contemporains, 42.

CYKNOS. Amatista. $100 \times 205$ mm. Nancy, 78.

Repite el modelo creado en el lienzo de "Á tire d'aile", de 19561961, del Museo de Artes Decorativas, de Paris, y el de la litografía de 1961. 

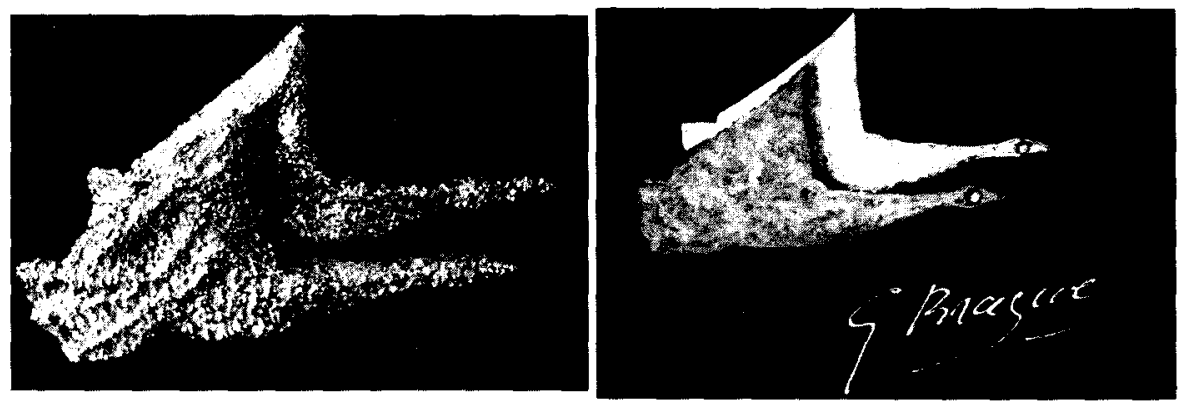

DELOS. Vigila sobre el Santuario de Apolo. Escultura. Pájaro de hilos de cobre dorado adornado de una amatista de 28 quilates, erigido sobre un bloque de amazonita bruta excepcional. $400 \times 420 \mathrm{~mm}$. Nancy, 101.

DEMÉTER. Imagen de la tierra fecunda. Sus lugares predilectos eran Eleusis y Sicilia, pero también Tracia y Creta. Pájaro. Ágatas paisaje enlazadas por una montura de oro que forma una caja, con cierre de diamantes, $54 \times 83 \mathrm{~mm}$. Bijoux de Braque, Museos de Niza, enerofebrero 1969, 73; Nancy, 43.
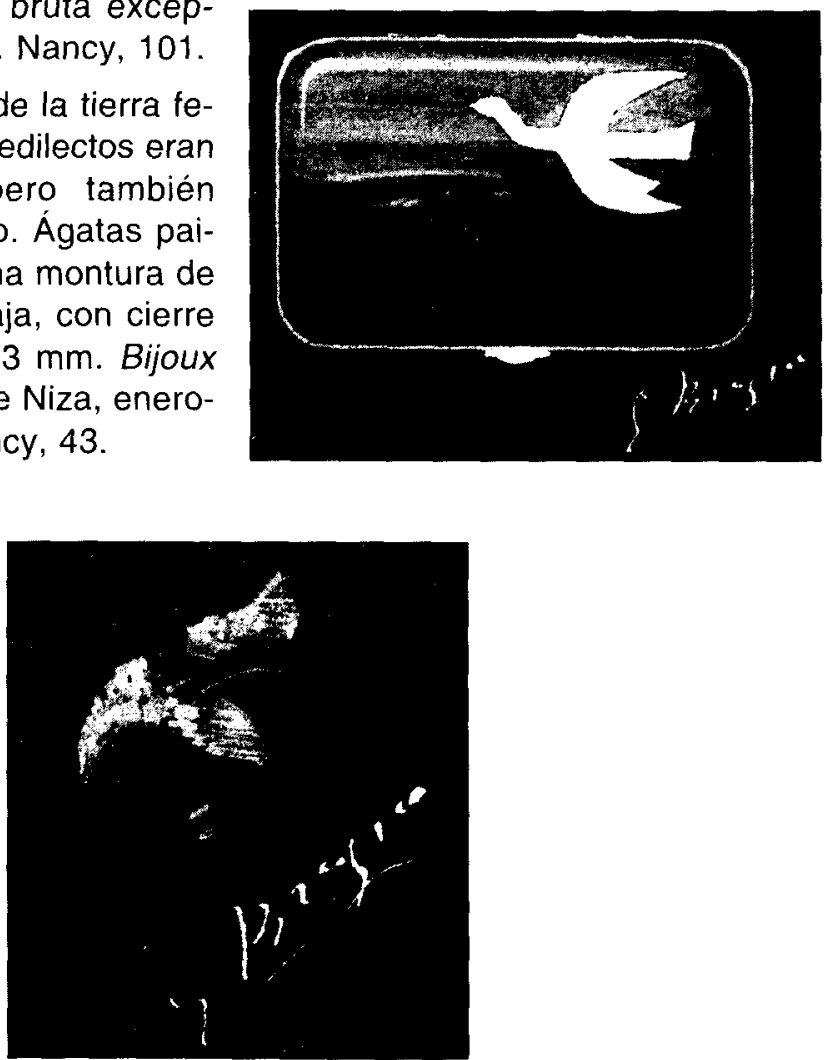

Dione. Perseguida como sus hermanas Parthénia y Calipso, se posa un instante. Anillo de oro calado, adornado con un pájaro de varillas de rubíes. Bijoux de Braque, Museos de Niza, enero-febrero 1969, 74. 


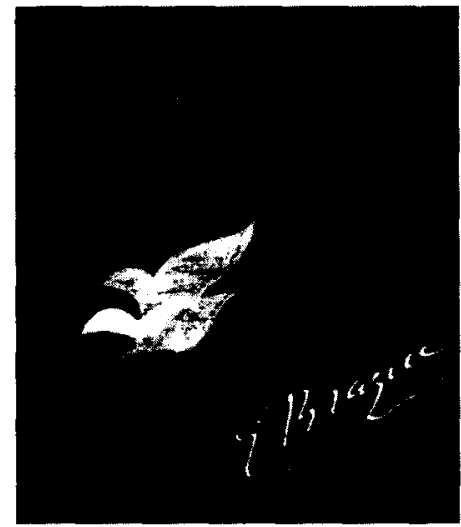

Dionisos. Llamado también Baco, es el dios de la viña, del vino y del delirio místico. Hijo de Zeus y de Semele. Era festejado en procesiones tumultuosas en que participaban los genios de la tierra y de la fecundidad.

Eos. Hermana de Helios, el sol, y de Selene, la luna. Ella personifica la Aurora. La diosa abre las puertas del cielo al carro del Sol. Clip. $55 \times 45 \mathrm{~mm}$. Pájaro de diamante sobre una nube de oro. Pertenece a Madame Marguerite Maeght. (Junto con los 4 siguientes en Bijoux de Braque ...) 1; Zurich, 1.

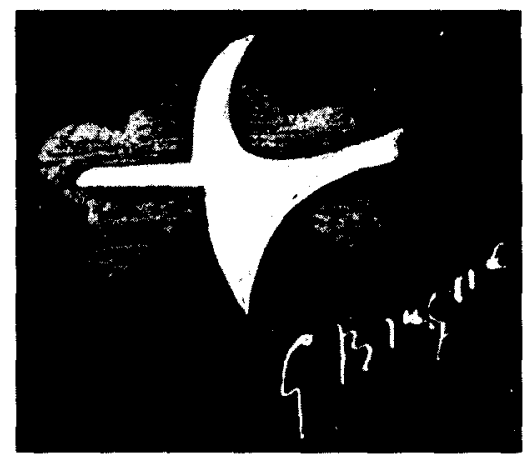

Eos IV. Eos se eleva en el cielo y el rocío matinal resplandece. Clip. 51 $\times 65 \mathrm{~mm}$. Pájaro de diamante sobre un fondo de oro punteado de topacios rosas. Bijoux de Braque, 23; Zurich, 23.

Eos $V$. Eos alza el vuelo hacia Zeus: ¿le concederá la inmortalidad a Titón? Pulsera de oro flexible. Pájaro y nubes de diamante. Motivo 45 x 45 $\mathrm{mm}$. Bijoux de Braque, 41; Zurich, 41.

EosVI. Eos vuela a socorrer a su hijo Memnon. Anillo de platino adornado con un pájaro de diamante. $23 \times 30 \mathrm{~mm}$. Bijoux de Braque, 33; Zurich, 33. 
EOS, LOS HIJOS DE. Faetón, Fósforos y Hespéros alzan majestuosamente el vuelo. Clip. $45 \times 80$ $\mathrm{mm}$. Pájaros de diamantes, de oro y de lapislázuli. Bijoux de Braque, 34; Zurich, 34; Nancy, 23.

EOS II, LOS HIJOS DE. Clip. $45 x$ $80 \mathrm{~mm}$. Pájaro de oro y de jade. Bijoux de Braque, Museos de Niza,

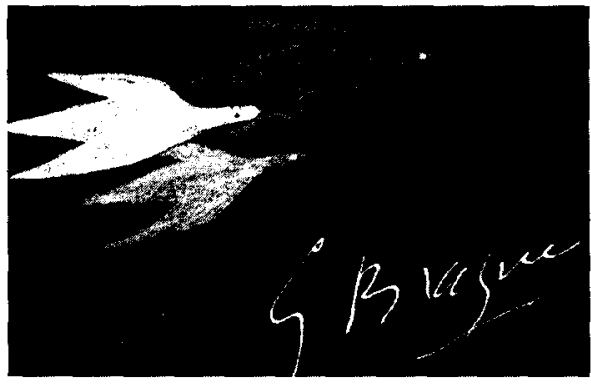
enero-febrero 1969, 34; Craven, 6.

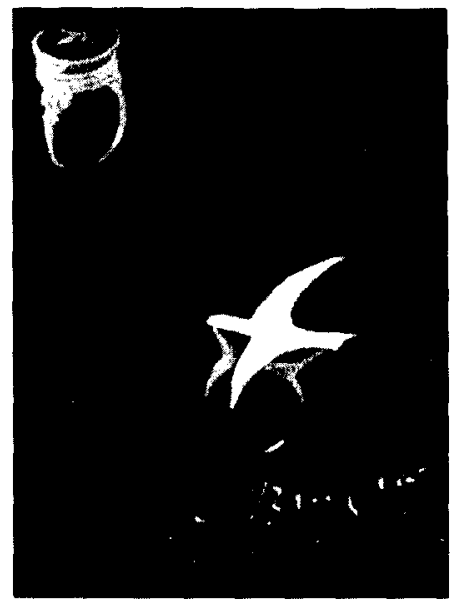

EOS, METAMORfosis DE. [1962] Al unirse a Ares, la diosa de la Aurora provoca la ira de Afrodita. Ha elegido este tema Braque para figurar por un doble valor sugestivo, el motivo plástico, el último gran tema que sella su obra sobre este anillo: el pájaro. Camafeo ónice bicolor. Sortija de sello en chevalière personal de Georges Braque. Altura total, 2,2 - diámetro 1,9. Firmado: G. Braque / Heger de Lowenfeld. Sortija realizada y ofrecida al artista por Heger de Lowenfeld para sus 81 años. El artista la llevó hasta su muerte. Donación con reserva de usufructo, de Madame Georges Braque en 1963; entrada en el Museo en 1965. Inv. AM 1207 OA. Exposiciones: París, 1963, n. ${ }^{\circ}$ 113; París, 1965, n. ${ }^{\circ} 21$ repr.; Darmstadt, 1967, n. ${ }^{\circ} 12$ repr.; Niza, 1969, n. $^{\circ}$ 113.- Bibl.: Fumet 1965, repr. P. 192.- Paris 1968, n. ${ }^{\circ} 113$; Zurich, 113 ; Nancy, 55.

Eósforos. La estrella de la mañana, hija de Eos, se eleva en el cielo y el rocío de la mañana brilla. Clip. $51 \times 65 \mathrm{~mm}$. Pájaro de diamantes 
sobre un fondo de oro punteado de turmalinas rojas. Bijoux de Braque, Museos de Niza, enero-febrero 1969, 23; Nancy, 17; Craven, 7.
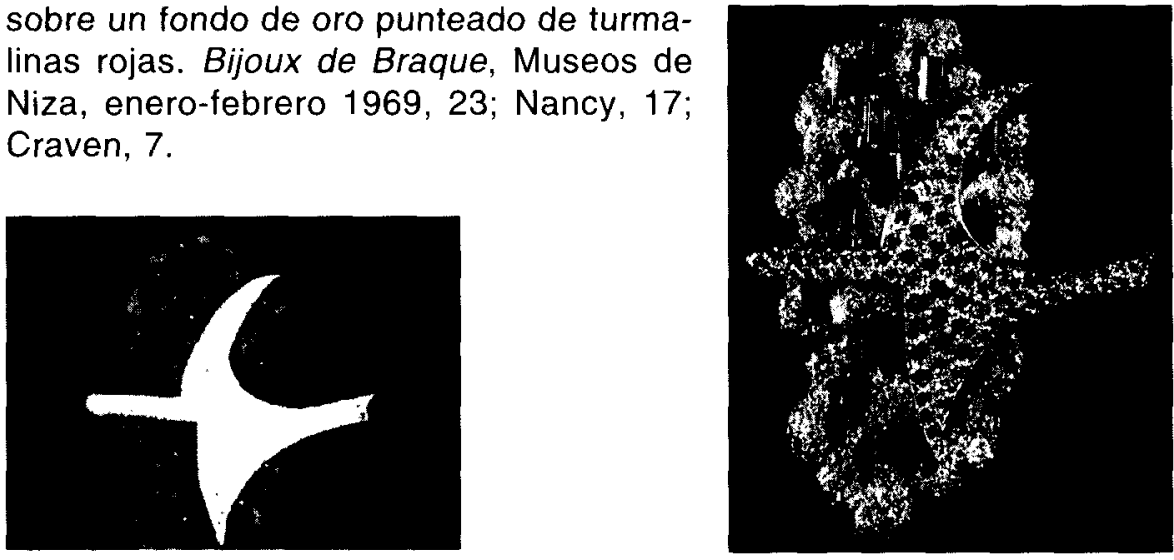

ERATO. Musa de la poesía erótica y del himeneo. Tocaba la lira. Utilizada en decoración de Gemelos.
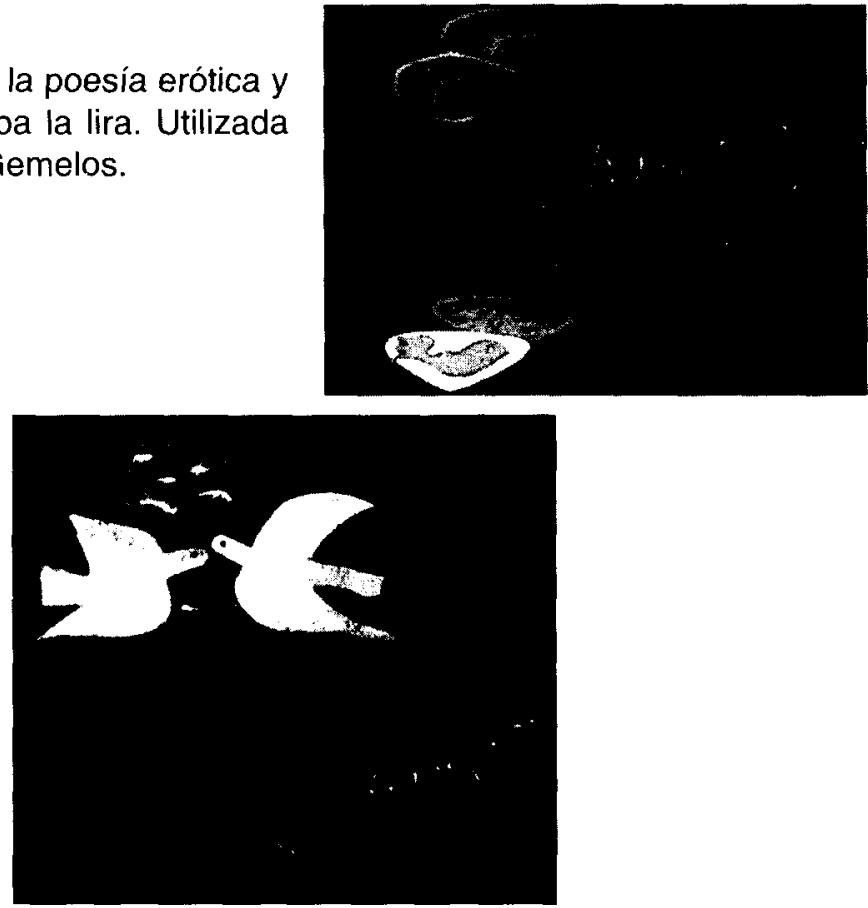

ERos y PSIQUE. Eros, dios del amor, y Psique, el nombre del alma, la heroína de una historia contada por Apuleyo en su Metamorfosis. Zeus consiente en unir a los dos amantes. Anillo de oro. $16 \times 20 \mathrm{~mm}$. Dos pájaros esculpidos en blanco sobre rosa en una cornalina bicolor y montados en un anillo abierto. Bijoux de Braque, Museos de Niza, enerofebrero 1969, 38; Zurich, 38; Nancy, 27. 
FAETón. Obra póstuma. Los impetuosos corceles de Helios arrastran al desventurado en una loca carrera que no puede controlar. Broche. $55 \times 92 \mathrm{~mm}$. Pájaro de oro con el ojo de rubí. Bijoux de Braque, Museos de Niza, enero-febrero 1969, 54; Nancy, 39; Craven, 7.

FAETÓN. Colgante ónice y oro. Bijoux Contemporains, 40.

FAETÓN II. Obra póstuma. Broche. $55 \times 92$ $\mathrm{mm}$. Pájaro de oro con el ojo de esmeralda. Bijoux de Braque, Museos de Niza, enerofebrero 1969, 54.

Repite, sucesivamente, sus gouaches y óleos del tema.
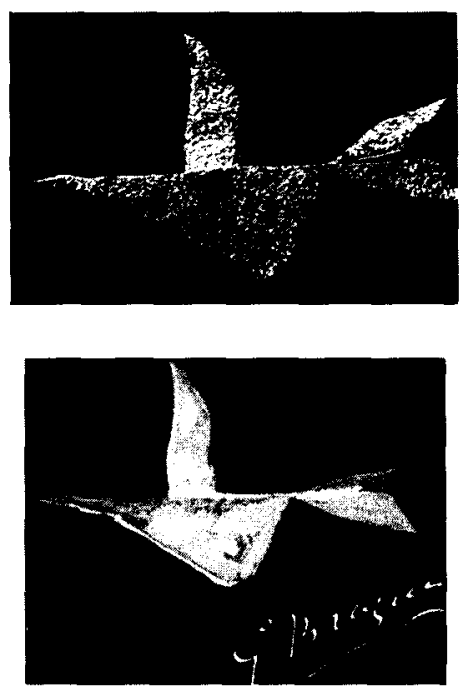

FÉNIX. ¡Fénix, el más bello de los pavos! Del mismo modo que el pájaro fabuloso anunciaba la revolución sideral, Braque garantizó la revolución pictórica. Pájaro de oro iluminado con esmaltes multicolores con adorno de diamantes, persistencia de la paleta de Braque. $63 \times 70 \mathrm{~mm}$. Bijoux de Braque, Museos de Niza, enero-febrero 1969, 49; Zurich, 49; Nancy, 35; Craven 15.
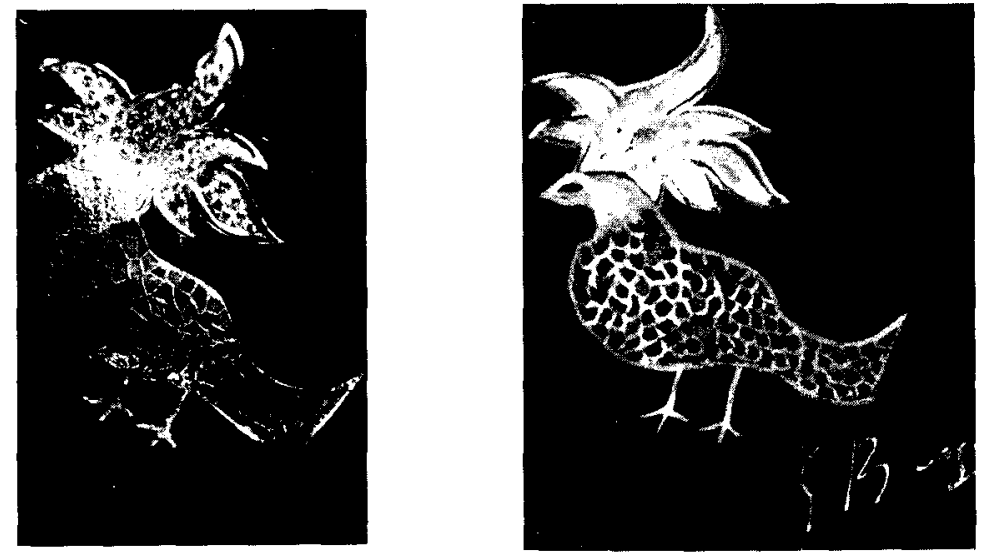

FILACOS. Al igual que su hermano, se vio beneficiado por la clemencia divina y conoció su mismo destino. Pájaro esculpido en negro sobre blanco en un ónice bicolor de $23 \times 30 \mathrm{~mm}$. Bijoux de Braque, Museos de Niza, enero-febrero 1969, 37; Nancy, 26. 
HaRPia. Perseguida por Zetes y Calais, se arroja al río que lleva su nombre. Pájaro esculpido verde sobre negro en un ónice bicolor. $15 \times 21$ $\mathrm{mm}$. Nancy, 89.

HÉlENE. Subyugado por su belleza, Paris se enamora de ella y la rapta en Ménélas. Pájaro de oro perfilado sobre trazos de esmalte azul con diamantes.

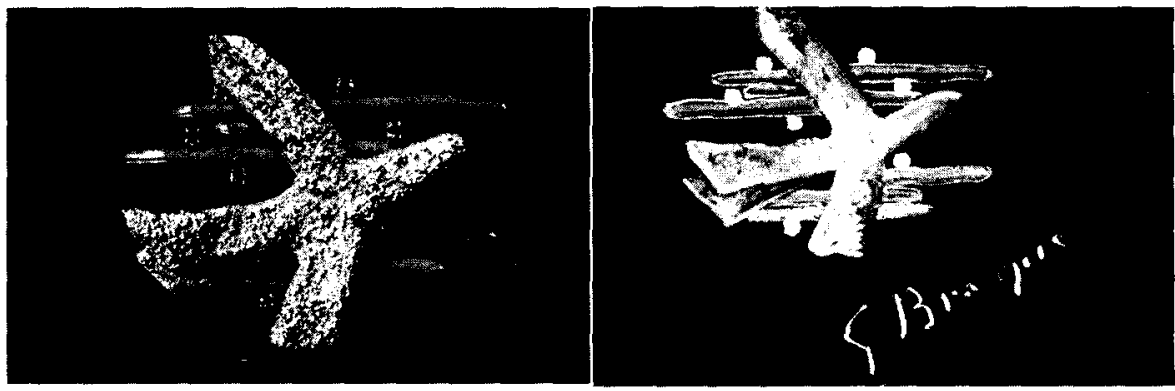

HELIADE. Recoge piadosamente a Faetón. Pájaro grabado en una cornalina indiana montada en una nube de oro. $78 \times 39 \mathrm{~mm}$. Nancy, 20 .

Hematión. Nació en el país del sol de los amores de Eos y de Tithonos. Pulsera de oro blando y desgastado punteado de diamantes, que lieva un pájaro de diamantes. $45 \times 45 \mathrm{~mm}$. Bijoux de Braque, Museos de Niza, enero-febrero 1969, 41; Nancy, 29; Craven, 31.
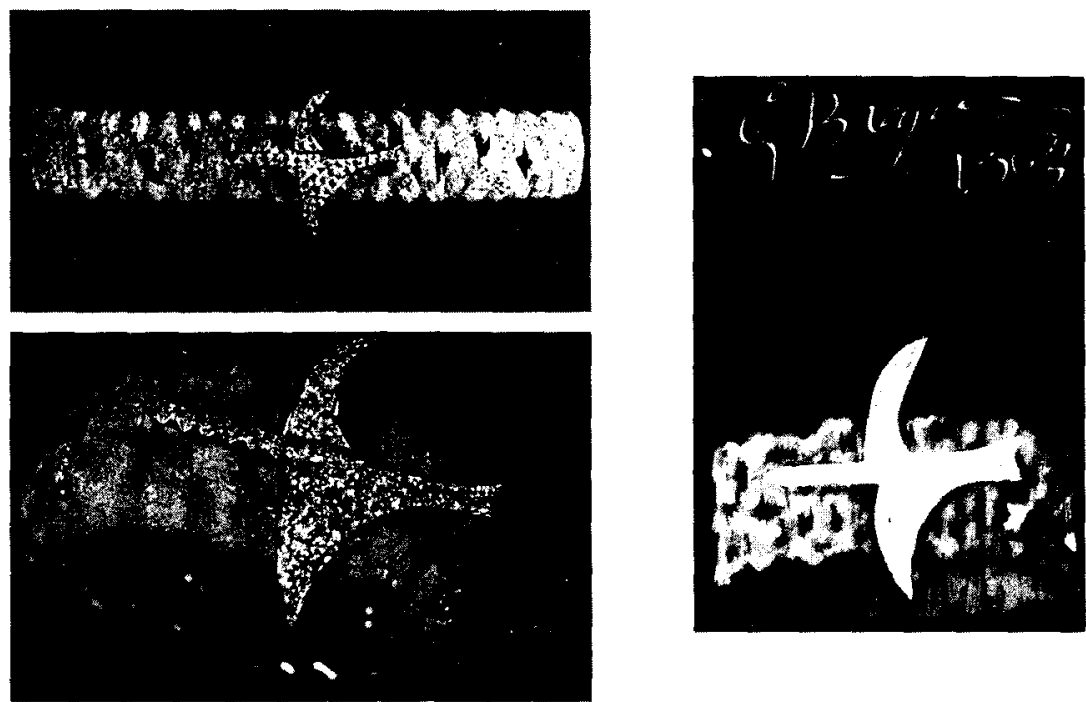


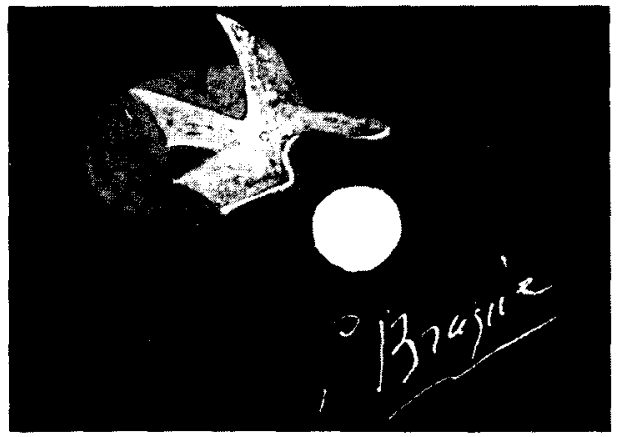

HEMÉRA. La diosa viene a traer a los hombres la luz del día. Clip. $41 \mathrm{x}$ $52 \mathrm{~mm}$. Pájaro de diamantes y astro de ópalo de fuego sobre una nube de oro. Arquetipo adquirido por el Estado francés. Bijoux de Braque, Museos de Niza, en-febr 1969, 3; Zurich, 3.

HEMERA II. Clip. $41 \times 52 \mathrm{~mm}$. Pájaro de turquesas y astro de diamante, sobre una nube de oro. Bijoux de Braque, Museos de Niza, enero-febrero 1969, 3; Nancy, 2; Staedler, 3.

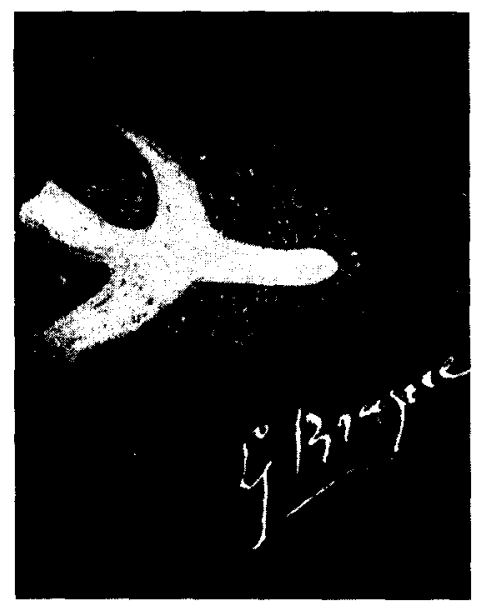

HERO. Joven hija amada de Leandro, por la que atravesaba por la noche, a nado, iluminado por la luz que ella le arrojaba, el río que la separaba de él.

HESPÉRIDES, LAS. Son las «Ninfas del Poniente». Las descendientes de Eos vigilan el jardín de los Dioses. Tres pájaros esculpidos en negro sobre blanco en un ágata bicolor de $23 \times 30 \mathrm{~mm}$. Bijoux de Braque, Museos de Niza, enero-febrero 1969, 105; Nancy, 51. 
HESPÉRIDES II, LAS. Tres pájaros esculpidos en negro sobre blanco en un ónice bicolor de $15 \times 21 \mathrm{~mm}$. Bijoux de Braque, Museos de Niza, enerofebrero 1969, 106.

HESPEROS. "El más espléndido de los astros que brillan sobre la bóveda celeste". Pájaro esculpido en jade y en jaspe colocados sobre un ágata cercada. $16 \times 60 \mathrm{~mm}$. Nancy, 57 .

ICARIO II. Regresa a Lacedemonia para casarse con la náyade Périboéa. Clip. $45 \times 48 \mathrm{~mm}$. Pájaro de diamantes sobre un fondo de jaspe rojo engastado con oro. Adquirido por el Estado francés. Bijoux de Braque, Museos de Niza, enero-febrero 1969, 20; Zurich, 20.
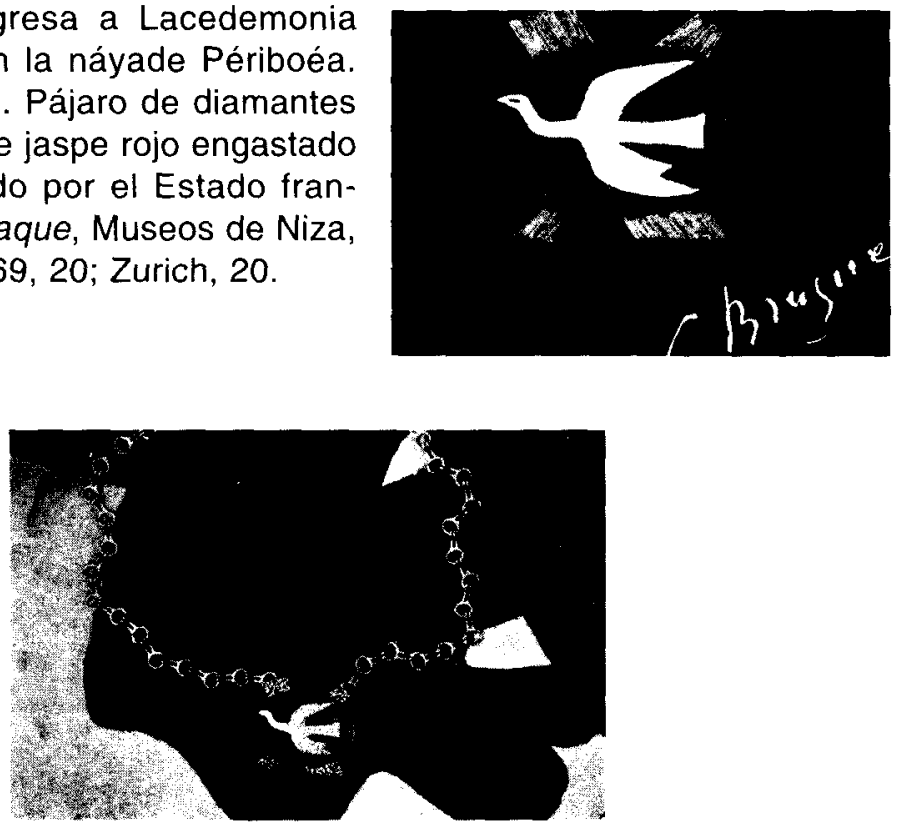

ICARIO III. Pájaro de oro gris sobre un fondo de cornalina cruzado de oro. $45 \times 48 \mathrm{~mm}$. Nancy, 14 .

Reproduce el llamado "Pájaro de fuego", aguafuerte, de 1958.

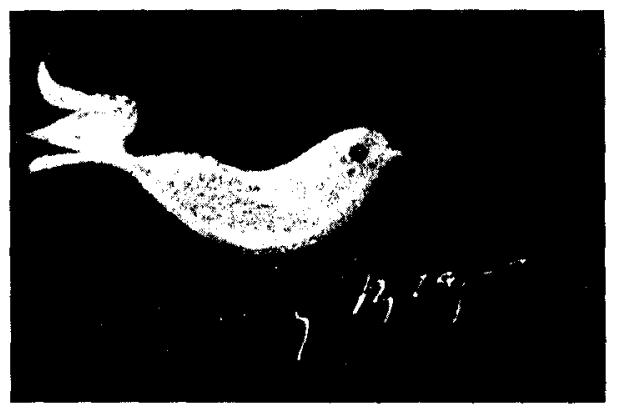


IRIS. Obra póstuma. Al igual que el arcoiris que une la Tierra al Cielo, une los Hombres a los Dioses. Diosa de los pies rápidos que volaba sobre el viento. Clip. $15 \times 56 \mathrm{~mm}$. Motivo de berilos degradados. Bijoux de Braque, Museos de Niza, enero-febrero 1969, 152.

IRIS. De un ligero vuelo, la diosa lleva a los mortales el mensaje de Zeus. Pájaro de oro. $15 \times 56 \mathrm{~mm}$. Nancy, 37 .

LACHÉSIS. ¿Puede ser el destino ciego y ser tan hermoso? Anillo de platino adornado con un pájaro de diamantes, de $20 \times 22 \mathrm{~mm}$. Bijoux de Braque, Museos de Niza, enero-febrero 1969,78 ; Zurich, 78.
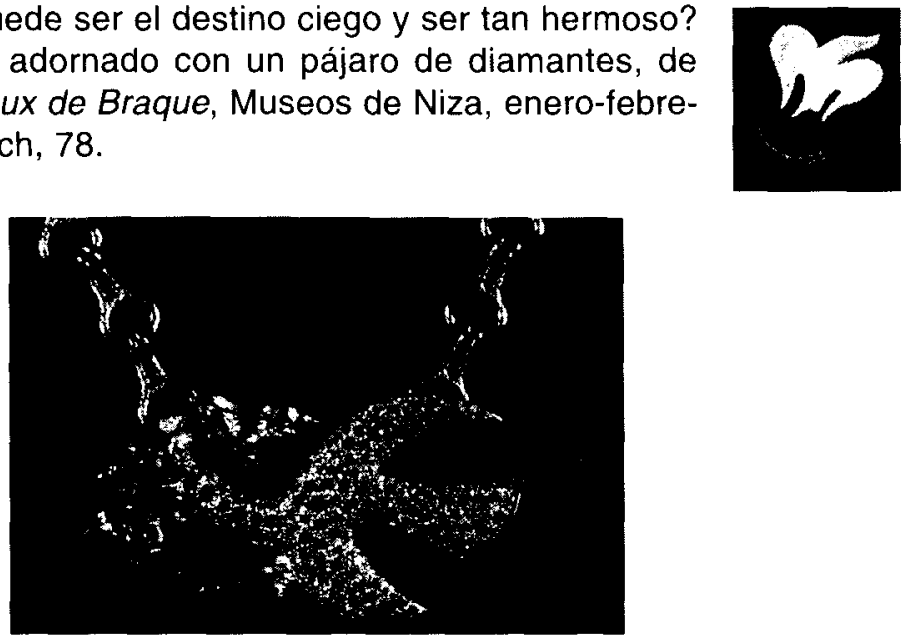

MÉGALETOR. Zeus rechaza verle perecer y lo transforma en golondrina. Clip. $68 \times 36 \mathrm{~mm}$. Pájaro de diamantes resalta sobre una nube de oro. Bijoux de Braque, Gimpel et Hanover Galerie ... Zurich 2, junio- julio 1963, 36. También colgante con cadena Mesopotamia.

Megaletor. Pájaro de zafiros y oro. $68 \times 36 \mathrm{~mm}$. Nancy, 25.

MEgaletor III. Puesto que se negaba a verlo morir, Zeus lo transformó en pájaro. Anillo de oro adornado con un camafeo. $15 \times 21 \mathrm{~mm}$. Pájaro esculpido en negro sobre blanco en un ágata bicolor. Bijoux de Braque, Museos de Niza, en-febr 1969, 100.
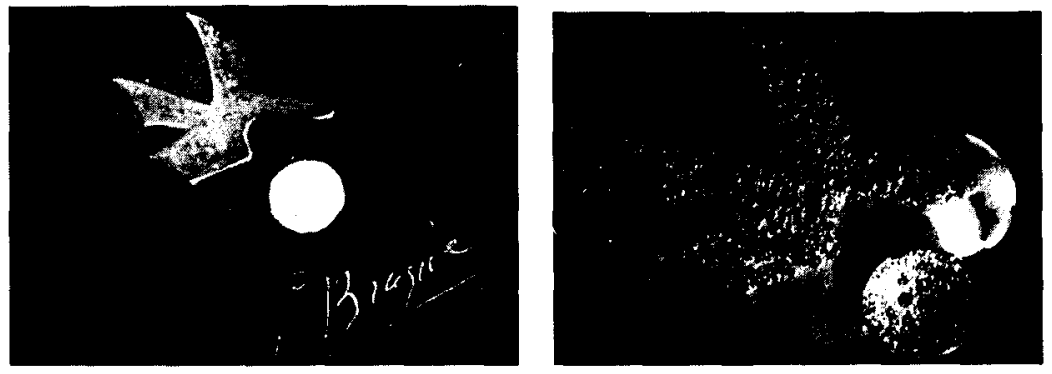
MEMNON. Sobre los muros de Babilonia, iluminado por la Aurora, su hijo acude a saludarla melódicamente. Clip. $45 \times 57 \mathrm{~mm}$. Pájaro de oro y astro de diamantes, sobre un fondo de turquesa. Bijoux de Braque, Museos de Niza, enero-febrero 1969, 14; Zurich, 14; Nancy, 9.

Minos y Procris. La inconstante esposa de Céfalo huye detrás de Minos al que libera de su encantamiento. Cadena de oro; colgante de oro adornado con un pájaro esmaltado. $37 \times 52 \mathrm{~mm}$. Nancy, 81 .

Notos. El hijo de Eos dispersa el ardiente viento del Sur. Pájaro esculpido en negro sobre blanco en un ónice bicolor de $15 \times 21 \mathrm{~mm}$. Montado en anillo con círculo de oro. Bijoux de Braque, Museos de Niza, enerofebrero 1969, 102; Nancy, 50.

Notos II. Pájaro esculpido en blanco sobre negro en un ónice bicolor de $15 \times 21 \mathrm{~mm}$. y montado en anillo de oro. Sortija de sello personal de Heger de Loewenfeld. Bijoux de Braque, Museos de Niza, enero- febrero 1969, 103.

Notos III. Pájaro esculpido en negro sobre blanco en un ónice bicolor de $23 \times 30$ mm. Bijoux de Braque, Museos de Niza, en-febr 1969, 104.

Notos IV. Hijo de la aurora y del Titán, es el viento venido de occidente. Pájaro esculpido en negro sobre blanco en un ónice bicolor de $23 \times 30$ $\mathrm{mm}$., engastado con un filete de oro.Montado como clip. Bijoux de Braque, Museos de Niza, en.-febr. 1969, 111; Nancy, 53.

PAJAROS Y LA NUBE, LOS DOS. Homenaje a Braque por Heger de Loewenfeld. Motivo esculpido en negro sobre blanco en un ágata bicolor de 23 × $30 \mathrm{~mm}$. Bijoux de Braque, Museos de Niza, enero-febrero 1969, 131.

PANDORA. En el mito de Hesíodo es la primera mujer. Fue creada por Hefaistos y Athena, ayudados por todos los dioses, por orden de Zeus. Cada uno le dio una cualidad y Hefaistos la había formado a imagen de las diosas inmortales. Se la representa similar a Procris, si bien Pandora representa el pájaro tallado en una piedra dura. Pájaro esculpido negro sobre blanco en un ónice bicolor. 23 x 30 mm. Exposición FRED, 1972; Craven, s.n.

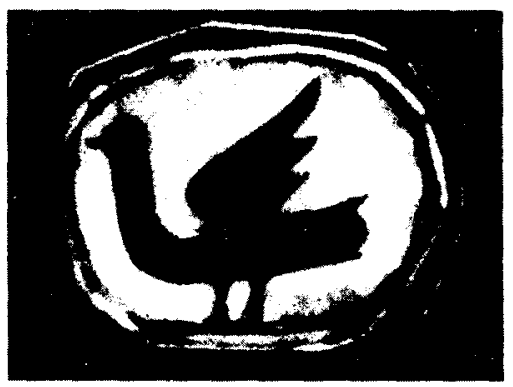


lconográficamente parece inspirado en el pájaro que otea en el lienzo del "Taller VI».

PANDOROS. Es uno de los hijos de Erecteo y Praxitea. Sólo la Esperanza no voló del vaso de Pandora. Pájaro de esmalte verde sobre bronce. $20 \times 15 \mathrm{~mm}$. Nancy, 90 .

PARTENIA. Durante cinco años, Orión perseguirá a las hijas de la Reina de las Amazonas. Clip. $45 \times 66 \mathrm{~mm}$. Pájaro de rubíes y de diamantes sobre un fondo de oro calado. Bijoux de Braque, Museos de Niza, en-febr 1969, 31; Zurich, 31cita a Partenia, Calipso y Dione, pero representa un solo pájaro. Staedler, 31; Craven, 25.
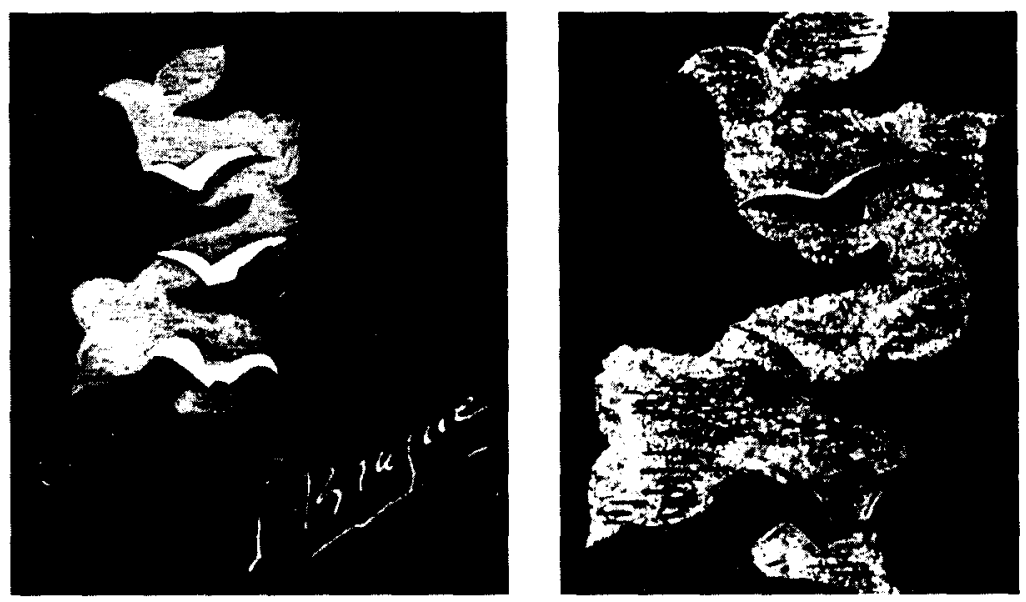

PARTENIA II. Zeus ha respondido a su llamada: se han transformado en pájaros y ahora pueden resistirse al encanto de Orión. Pendientes de clip de oro y diamante, $36 \times 25 \mathrm{~mm}$. Bijoux de Braque...., 43 .

PARTENIA III. En el mes de mayo, aparece en el cielo y nos anuncia el verano. Anillo de oro que lleva un pájaro de rubíes de Oriente en varillas calibradas. Bijoux de Braque.... , 74; Zurich, 74.

PÉLIAS Y NÉLEO. Los hijos de Poseidón, gemelos, se disputaban el poder en Tesalia. Neleo fue expulsado por su hermano. Pélias quiso ofrecer un sacrificio a Poseidón, al que acudieron hasta su sobrino Jasón. Avisado Pélias por el oráculo de que Jasón podía quitarle el trono, lo mandó en busca del vellocino de oro. Clip. Pájaro de lapislázuli, nube de oro punteado de diamantes navetas. Bijoux de Braque, Gimpel et Hanover Galerie ... Zurich 2, junio-julio 1963, 133. 

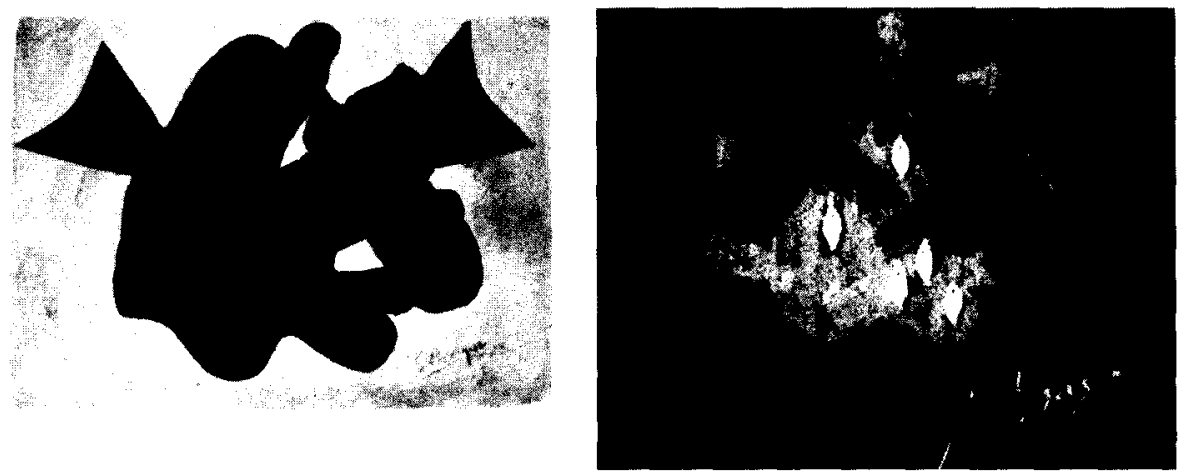

Peristera. Celoso de su amor por Afrodita, Eros la transforma en pájaro. Anillo de platino adornado con un pájaro de diamantes. Adquirido por el Estado francés. Bijoux de Braque, Museos de Niza, en-febr 1969, 75; Zurich, 75.

Peristera II. Anillo de oro adornado con un pájaro punteado de záfiros. Bijoux de Braque, Museos de Niza, enerofebrero 1969, 75.

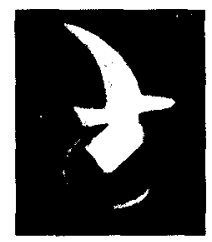

PléYADES, LAS. Perseguidas por los Montes de Beocia, las Pléyades son transformadas en pájaros. Clip. $45 \times 66 \mathrm{~mm}$. Pájaros de diamantes y rubies sobre un fondo de oro. Bijoux de Braque, Museos de Niza, enero-febrero 1969, 25; Nancy, 18; Zurich, 25; Craven, 27.
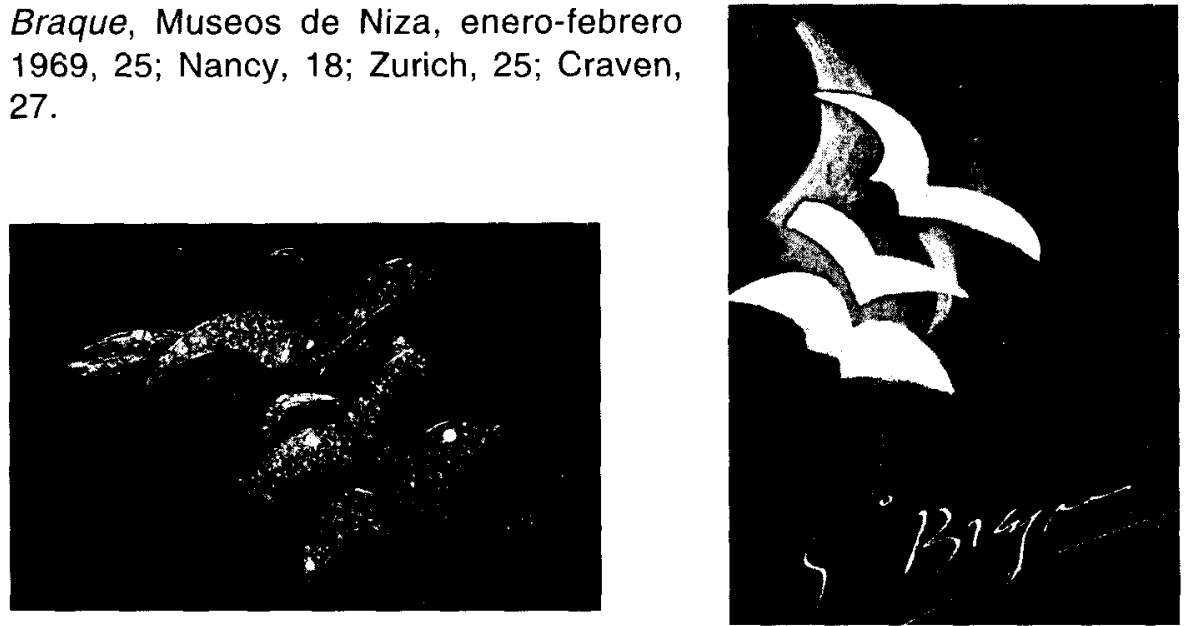
POSEIDÓN. Educado por los Telquines, se enamora de su hermana Halia.El dios violento se ablanda entre las olas. Collar de oro con motivos engastados de diamantes. Bijoux de Braque, Museos de Niza, enero- febrero 1969, 16; Zurich, 16; Staedler, 16; Craven, 32.
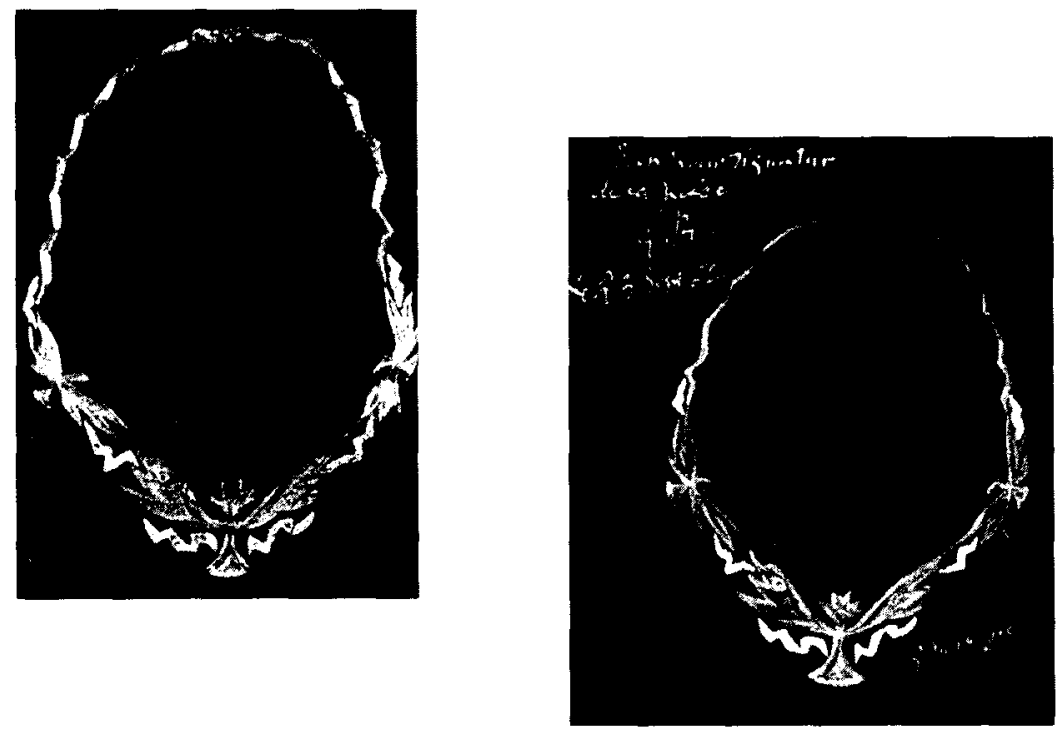

PROCNE. Transformada en golondrina, la hermana de Procris escapa a la espada de Tereo. Chevalier de oro y esmalte. $20 \times 15 \mathrm{~mm}$. Nancy, 104.
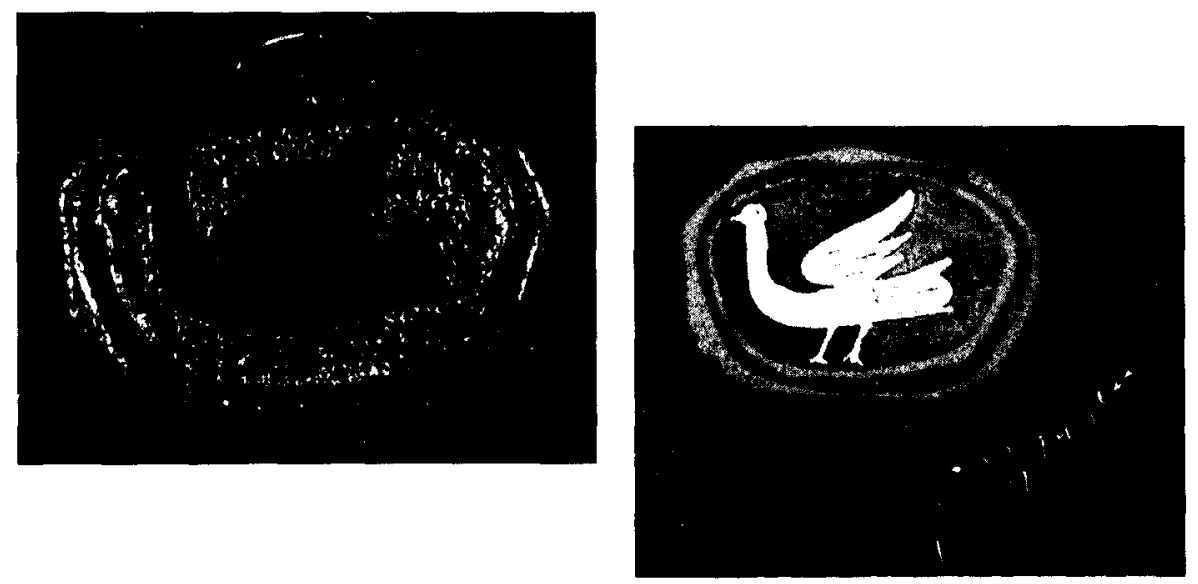

Procris. Pájaro en esmalte azul sobre fondo de oro. Zurich, 12. 
ProcRIS II. Tentada por la corona de oro, Procris alza el vuelo hacia Pteleón. Broche. $37 \times 52 \mathrm{~mm}$. Pájaro de esmalte tierra de Siena sobre fondo de oro. Bijoux de Braque, Museos de Niza, enero-febrero 1969, 12; Craven, 12.

ProcRIS V. Colgante. $37 \times 52 \mathrm{~mm}$. Pájaro con esmalte oscuro sobre fondo de oro. Staedler, 12.

CADENA DE PROCRIS. Si Procris así lo hubiera ordenado, habría retenido a Céfalo. Cadena de oro. Bijoux de Braque, Gimpel et Hanover Galerie, Zurich 2, jun-jul 1963, 46.

SYME. Hija de lalysos, fue raptada por Glaucos. Éste conquistó una isla, próxima a Rodas, a la que dio el nombre de su esposa.

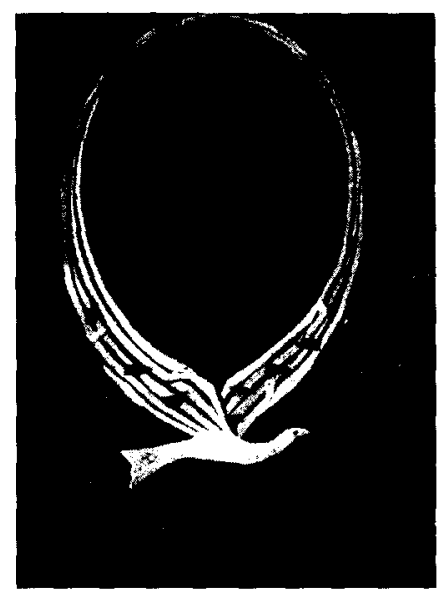

TALIA. En el cortejo de Apolo, la hija de Hefaistos lleva la máscara cómica. Dos pájaros de oro en diferentes texturas. $5 \times 24 \mathrm{~mm}$. Nancy, 92 .

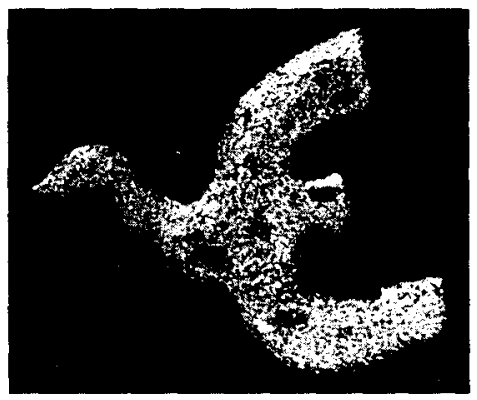

TEREO. Obra póstuma. Deseoso de matar a Procné y Filomeno, el rey de Tracia es transformado en pájaro. Clip. 48 x $55 \mathrm{~mm}$. Pájaro de oro engastado de turquesa. Bijoux de Braque, Museos de Niza, enero- febrero 1969, 56; Craven, 10.

TEREO. Pájaro de oro con rubies engastados. $48 \times 55 \mathrm{~mm}$. Nancy, 40 .

TEREO II. Obra póstuma. Clip. $48 \times 55 \mathrm{~mm}$. Pájaro de oro engastado de zafiros. Bijoux de Braque, Museos de Niza, enero-febrero 1969, 56. 


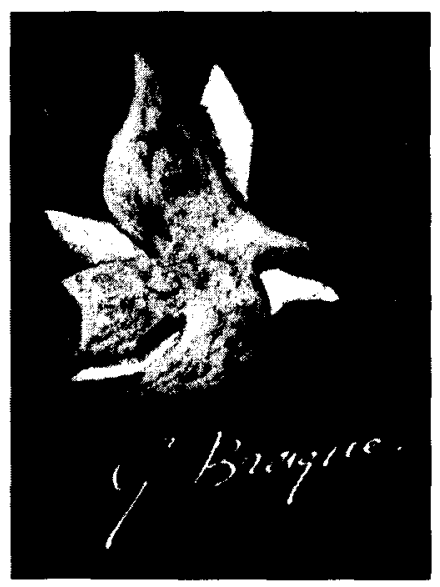

THYRIA. Al querer acompañar a su hijo Cycnos hasta el límite de su destino, se ve como él transformada en cisne. Clip. Pájaro de oro desgastado con el ojo punteado con un rubí. $68 \times 50 \mathrm{~mm}$. Bjoux de Braque, Museos de Niza, enero-febrero 1969, 145; Nancy, 73.

THYRIA II. Clip. Pájaro de oro desgastado con el ojo punteado con una esmeralda. Bijoux de Braque, Museos de Niza, enero-febr. 1969, 145.

Titonos. El brillante héroe alza el vuelo hacia la Aurora a la cual ha subyugado. Clip. $41 \times 75 \mathrm{~mm}$. Pájaro de oro adornado con diamantes. Bijoux de Braque, Museos de Niza, enero-febr. 1969, 5; Zurich, 5; Zurich, 5; Staedler, 5.
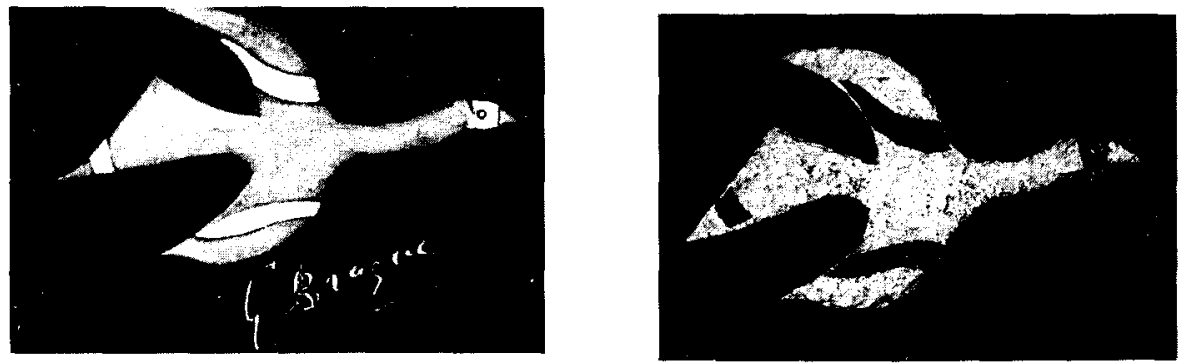

Titonos II. Clip. $41 \times 75 \mathrm{~mm}$. Pájaro de oro adornado con zafiros. Bijoux de Braque, Museos de Niza, en-febr 1969, 5; Craven, 9.

Titonos II. Pájaro de oro adornado con rubies. $41 \times 75 \mathrm{~mm}$. Nancy, 4 . 
TRES GRACIAS, LAS. Las compañeras de Afrodita van a adornar suntuosamente a la diosa. Clip. $60 \times 66 \mathrm{~mm}$. Pájaros de diamantes, de oro y de calcedonia. Bijoux de Braque, Museos de Niza, enero-febrero 1969, n. ${ }^{\circ} 39$, y Zurich, 1963, n. $^{\circ} 39$. CRAVEN, 1969, p. 75 y n. ${ }^{\circ} 12$; Nancy, 28.

TRES GRACIAS, LAS II. Clip. $60 \times 66 \mathrm{~mm}$. Pájaros de oro y de rodocrosita. Bijoux de Braque, Museos de Niza, enero-febrero 1969. Gal. Staedler, $1968, n^{\circ} 39$.

Tres Gracias, Las II. Cip. $60 \times 60 \mathrm{~mm}$. Pájaro de oro pulimenatado, oro mate y oro corroído. Gal. Staedler, $1968, n{ }^{\circ} 39$.
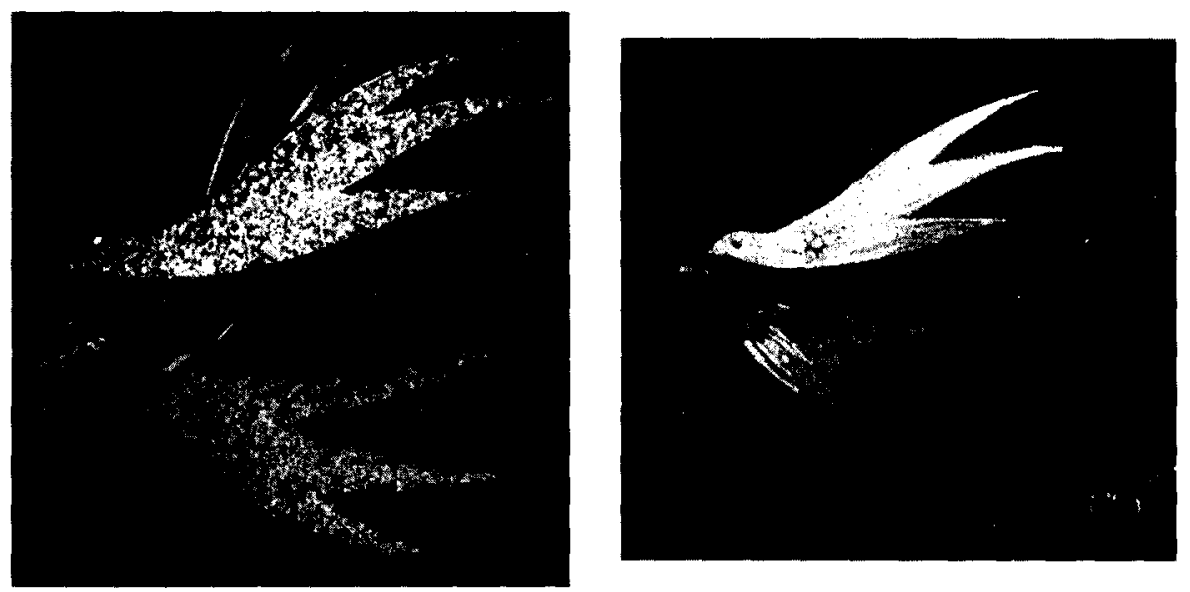

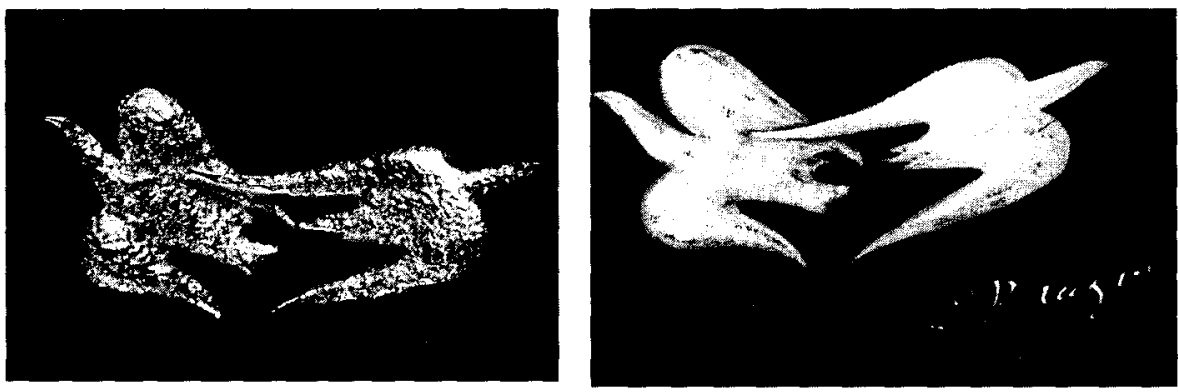

ZETES Y CALAIS II. Uno amaba la lucha, el otro la lira. Clip. $43 \times 95 \mathrm{~mm}$. Pájaros de oro, adornados con ojos de rubies. Bijoux de Braque, Museos de Niza, enero-febrero 1969, y en Zurich, 1963, n. ${ }^{\circ}$ 53. John CRAVEN, $\mathrm{n} .^{\circ} 8$ y n. ${ }^{\circ} 53$, p. 16; Bijoux des artistes contemporains, n. ${ }^{\circ} 18$. Gal. Staedler, 1968, n. ${ }^{\circ} 53$; Nancy, 38; Zurich, 53.

Zetes Y CALAIS III. Clip. $43 \times 95 \mathrm{~mm}$. Pájaros de oro adornados con ojos de zafiros. Bijoux de Braque, Museos de Niza, enero-febrero 1969, y en Zurich, 1963, n. ${ }^{\circ}$ 53. Gal. Staedleer, 1968, n. ${ }^{\circ}$ 53. CRAVEN, 1969, p. 77 y n. ${ }^{\circ} 8$.

Ambos se plasman en el frontispicio de "La Teogonia" de Hesiodo, decorada en 1953 por Braque con aguafuertes y grabados. 
. 